\title{
KUTSAL ZAMAN, ALGILANIŞ BİÇİMI VE İBADET HAYATINA ETKİSİ
}

\author{
Muammer CENGİL * \\ Dilâ BARAN TEKİN*
}

\begin{abstract}
Özet:
İnsanlar hangi dini geleneğe bağlı olursa olsun, zamanı algılama ve yorumlama sürecinde pek çok faktörün etkisi altında kalmışlardır. Bu nedenle zaman, hem kişisel hem de toplumsal açıdan farkıı biçimlerde algılanan bir kavram olarak karşımıza çıkar. Dinî açıdan bakıldığında ise belli zaman dilimlerine kutsallık atfedildiği görülür ve zamanın kutsallaşması, kutsal varlık ile arasındaki ilişkiye bağlı olarak gerçekleşir. Böylelikle kutsallaşan zaman dinin etkin olarak hissedildiği anı ifade ederek insanın dinî hayatı içerisinde önemli bir yere sahip olur. Bu çalışma, zamanın kutsallığını ve ibadet üzerindeki etkilerini ele almaktadır. Birinci bölümde, din bilimleri içerisinde önemli bir yere sahip olan kutsal zaman kavramı üzerinde durulmuş ve söz konusu kavramın çeşitli dinlerdeki yansımaları dikkate alınarak genel bir değerlendirme yapılmıştır. İkinci bölümde ise, İslam geleneğinde yer alan kutsal zamanlar ile ilgili inanç ve davranışları anlamaya yönelik uygulanan anket sonuçlarına ve SPSS programında t- testi kullanılarak yapılan istatistiksel analizlere yer verilmiştir.
\end{abstract}

Anahtar kelimeler: Kutsal, Kutsal Zaman, Bayram, Kandil, İbadet.

\section{Sacred Time, It's Perception and Effects on Worship}

\section{Abstract:}

People has been under the influence of countless factor on perception and explication process of time for whatever religion they believe in. Therefore, time confront us as a notion which is perceived differently in terms of both personal and communal. When considering from the point of religious in case, it is seen that attributed sacredness to definite time periods and sacralization of time takes shape depending on relation with sacred being. Thus the sacralized time has had an important place within religious life of human being. This study focuses on sacred time and its effects on worship. In first section, it is discoursed the notion of sacred time which has an important place among sciences of religion and it is evaluated the reflections of sacred time. In the second section, it is discussed survey results which is taken a poll related to sacred times intended to understand the faiths and behaviors within İslamic tradition and statistical analyses which are made in SPSS programme by using t- test.

Key Words: Sacred, Sacred Time, Bairam, Kandil, Worship.

\section{Giriş}

Kutsalın ve kutsala yönelik tecrübelerin insan yaşamında önemli ve belirleyici bir rolü vardır. Dinî geleneklerde daha çok doğaüstü varlıklarla bağlantılı üstün bir güç olarak kabul edilen kutsal olgusu, metafizik âlem, tanrı ve tanrıyla ilgili her türlü ilişkiyi kapsayan geniş bir içeriğe sahiptir.

* Doç. Dr, Hitit Ü. İlahiyat Fakültesi Öğretim Üyesi.

** Arş. Gör., Hitit Ü. İlahiyat Fakültesi. 
Bu nedenle kutsal, din bilimleri içerisinde sıkça tartışılan bir konu olmuş ve dinleri açıklamada her daim merkezî bir konumda tutulmuştur. O halde araştırmamızın konusunu oluşturan kutsal zaman kavramını irdelemeye geçmeden önce kutsalın ne olduğu üzerinde durmak faydalı olacaktır.

\section{1. "Kutsal" ve "Kutsal Zaman" Kavramları}

Tarihî süreç içerisinde değerlendirildiğinde ilk kez Durkheim tarafından ortaya atıldığı günden bu yana pek çok araştırmacının farklı şekillerde ifade ettiği kutsal kavramına ilişkin yapılan tanımlamaların, genel olarak kutsal ile kutsal olmayanın karşılaştırılmasına dayalı bir yaklaşım içerisinde ele alındığı görülmektedir. Söz konusu yaklaşımın, kutsalı kutsal olmayanla yani profanla açıklamaya yönelik bir nitelik taşıdığını söylemek mümkündür. Bu anlayışa göre en genel anlamıyla kutsal, profanın zıddı olarak tanımlanmıştır. ${ }^{1}$ Bahsi geçen zıtlık, profanın sıradanlık, alelâdelik gibi özelliklere sahipken, kutsalın ise sıra dışılık, olağanüstülük gibi özellikler taşımasından kaynaklanır. ${ }^{2}$ Durkheim tarafından ileri sürülen kutsal fikrinin din bilimleri içerisindeki gelişimi sonraki dönemlerde Rudolf Otto, Joachim Wach, Van Der Leeuw, Mircea Eliade gibi isimlerin katkısıyla daha geniş bir mahiyete ulaşmıştır. Nitekim Durkheim kutsal kavramını din-toplum ilişkisi çerçevesinde değerlendirirken ${ }^{3}$, Otto daha çok onun irrasyonel ve gizemli yönü üzerinde durmuş ${ }^{4}$, Eliade ise kutsalı evrensel boyutu olan bir fenomen olarak ele alıp inceleme yoluna gitmiştir. ${ }^{5} \mathrm{O}$ halde zaman içerisinde geçirdiği kavramsal aşamaları göz önünde bulundurarak genel ve anlaşılır bir tanım yapacak olursak, kutsalın "tabiatüstü varlıklarla ilişkili aşkın bir güç” olduğunu söyleyebiliriz.

Dinî hayat ile ilgili olguların tümü kutsal ve profan olarak iki gruba ayrıldığından, zamanın da söz konusu ayrım içerisindeki yerini aldığı belirtilmeli-

1 Mircea Eliade, The Sacred and The Profane, trans. Willard R. Trask, Harcuort Brace, New York 1959 , s. 10 .

2 Şinasi Gündüz. "Kutsal Hakkında Konuşmak: Dinsel Söylemde Mitos”, Milel ve Nihal, 2009, c. 6 , say1 :1, ss. 10-11.

3 Durkheim The Elementery forms of Religious Life isimli eserinde dini, kutsal açısından değerlendiren anlatımlara yer verir. Ona göre dinî gelenekler içerisinde yer alan tüm olgular kutsal ve profan olmak üzere iki kategoriye ayrılır. Söz konusu ikiliğin kaynağını oluşturan temel etken ise toplumdur. Bu bağlamda Durkheim'ın kutsalı toplumla, profanı ise bireyle ilişkilendiren bir anlayışa sahip olduğu söylenebilir. bkn. Emile Durkheim, The Elementery Forms of Religious Life, trans. Karen E. Fields, The Free Press, New York 1995.

4 bkn. Rudolf Otto, The Idea of the Holy, trans. John W. Harvey, Oxford University Press, London 1936.

5 bkn. Eliade, The Sacred and The Profane; Mircea Eliade, Dinler Tarihi Inançlar ve İbadetlerin Morfolojisi, çev. Mustafa Ünal, Serhat Kitabevi, Konya 2005. 
dir. Bu bağlamda, içinde bulunduğumuz zaman kutsal zaman ve profan zaman olmak üzere iki türden oluşur. Kutsal zaman, kutsalın tezâhür zamanıdır ve kutsal olmayan zamanla kesintiye uğrayan bir süreklilik arz eder. İnanırlar bu iki farklı zaman türü arasındaki geçişi ritler aracılığıyla sağlarlar. ${ }^{6}$ Eliade'ın hiyerofanik zaman olarak ifade ettiği kutsal zamanın en büyük özelliği, tekrar edilebilir olmasıdır. Zira ritüellerin ilk olarak kutlandığı olay ânı ne kadar eskiye giderse gitsin, şimdiki zamana taşınarak tekrar temsil edilir. Örneğin, pazar günlerinde yapılan Hıristiyan ayini, daha önceki pazar ayinlerinden destek alırken, daha sonrakilerini de destekler. Bu ayinlerdeki ekmek ve şarabın İsa'nın etine ve kanına dönüşmesi, ilk kez gerçekleştirildiği andan itibaren günümüze kadar gerçekleştirilen bütün ekmek-şarap takdisi ayinlerinin bir devamıdır. ${ }^{7}$ Bu durumda ayin günleri kutsal, iki ayin arasındaki zaman ise profandır. Hıristiyan geleneğinde yer alan bu uygulamanın diğer bütün dinlerde var olan ritüeller için de geçerli olduğunu söylemek mümkündür. Öyleyse ritüellerin kutlandığı olay anına ilişkin yeniden meydana geliş ve tekrarlanış, kutsal zaman kavramının sürekliliğini sağlayan en temel etkendir diyebiliriz.

Çeşitli dinî geleneklerde farklı şekillerde ortaya çıkan kutsal zamanlar ya Tanrı'nın bir işareti sonucu özelleşmiş ya da insanlar tarafından sonradan kutsallaştırılmıştır. Birinci oluşumda, doğrudan Tanrı'nın kendisini açı̆̆a vurması ya da peygamberleri aracılığıyla iletişim kurması söz konusu iken, ikinci oluşumda ise zamanın kutsallaştırılması daha çok sosyo-kültürel bir ihtiyaçtan ortaya çıkar. Yahudiler için Fısıh ve Çardak günlerinin Eski Ahit'te, Müslümanlar için Ramazan Ayı ve Kadir Gecesi'nin ise Kuran'da bizzat Allah'ın bildirmesine dayalı olarak kutsal kabul edilmesi, ikinci oluşuma örnek olarak gösterilebilir. ${ }^{8}$

İlkel dönemlere bakıldığında kutsal zamanın tabiat hayatıyla ilişkilendirildiği görülmektedir. Buna bağlı olarak söz konusu dönemlerde kutsal zamana yönelik gerçekleştirilen kutlamaların daha çok tabiat bayramları şeklinde ortaya çıktığını söylemek mümkündür. $O$ halde kutsal zaman-tabiat ilişkilendirmesinin altında yatan en önemli neden, tabiatın, Tanrı'nın bir tezahürü olarak kabul edilmesidir. Eski dönemlerde çiftçilikle uğraşan kabilelerin ekin ve hasat bayramları, tabiatın yeniden doğuşunun kutlandığı bahar bayramları, ziraatçı toplumlarda gündönümü ve ekinoksun kutlandığı güneş bayramları ile yeniay ve dolunay kutlamaları, tabiat bayramları olarak

6 Eliade, The Sacred and The Profane, s. 68.

7 Eliade, Dinler Tarihi, Inançlar ve İbadetlerin Morfolojisi, ss. 457-463.

8 İlbey Dölek, “Kutsal Bir Zaman Dilimi Olarak Noel Ritüelinin Kutlama Gelenekleri, Alman Luteryanlar Örneği", Turkish Studies, Volume 9/10, Fall 2014, Ankara, ss. 372-373. 
kutlanan kutsal zamanlardır. Örneğin, Türklerde ve diğer Orta Asya kavimlerinde kutlanan Nevruz ${ }^{9}$ bir bahar bayramıdır ve ilkbaharın gelmesiyle birlikte pek çok ülkede kutlanır. ${ }^{10}$

Eski dönemlerde kutlanan tabiat bayramları zaman içerisinde değişime uğramış, bu bayramların yerini tarihî hadiseler ve din kurucularıyla ilgili olaylara dayalı kutlamalar almıştır. Bu nedenle günümüzde çeşitli dinlerde kabul gören kutsal zamanlar çoğunlukla, ait oldukları dinin önemli şahsiyetleri ile bağlantılı dinsel törenler olarak karşımıza çıkar. Örneğin, Caynistler Mahavira'nın, Budistler Buda'nın, Hindular Ganeşa ve Krişna'nın doğum gününü kutlarlar. Hıristiyanlarca İsa'nın doğumu ve hayatının çeşitli safhaları, Müslümanlarca Hz. Muhammed' in doğumu ve miracı kutlanır. ${ }^{11}$ Bunlar Tanrı tarafından bildirilen değil, insanlar tarafından zamanla kutsallaştırılan ayin ve törenlerdir.

Belirli bir olay ve düşünceye dayalı olarak ortaya çıkan kutsal zamanın dönüşümlü bir şekilde kutlanabilmesi için dinî takvimler oluşturulmuştur. Tarihin erken dönemlerinde, dünyanın ve ayın dönüşümünden ilham alınarak oluşturulan bu takvimler dairesel olarak ilerler. Bunun altında yatan en önemli neden, ilk âna dönebilme arzusudur. Zira dairesel zaman esas alınarak oluşturulan zaman çizelgeleri hem ilk âna dönebilme imkânı sağlar, hem de kutsalın sonsuzluğunu simgeler. ${ }^{12}$ Böylelikle insanlar takvimlere dayalı olarak, kutsal kabul ettikleri zamanların yıldönümlerini kutlama şansı bulurlar. İnananlar için bu zaman dilimleri diğer zamanlardan farklı ve özeldir. Bu zamanlarda daha içten ve samimi bir şekilde dua ederler. Bu sayede, Tanrıya daha yakın olduklarına inanırlar. ${ }^{13}$ Söz konusu durumun, insan ile kutsal zaman arasındaki psiko-sosyal ilişkiyi ortaya koyan bir niteliğe sahip olduğu söylenebilir. Nitekim bütün dini geleneklerde kutsal ve kutsala yönelik tecrübeler insan yaşamının önemli bir parçasını oluşturur. Dolayısıyla insanın kutsal olarak kabul ettiği değerleri ve kutsalla ilişkili değerlendirmelerini dikkate almadan insan davranışlarını anlamak mümkün değildir. ${ }^{14}$

9 Nevruz kutlamaları ile ilgili ayrıntılı bilgi için bkn. Nadir Devlet (Editör), Türk Dünyası'nda Nevruz, Marmara Üniversitesi - Türkiyat Araştırmaları Enstitüsü Yayınları, İstanbul 1999; Öcal Oğuz (Editör), Türk Dünyası Nevruz Ansiklopedisi, Atatürk Kültür Merkezi Başkanlığ1 Yayınları, Ankara 2004.

10 Ekrem Sarıkçıŏlu, Din Fenomenolojisi, Fakülte Kitabevi, Isparta 2011, s. 101.

11 Sarıkçığlu, age, s. 104.

12 Mustafa Ünal, Dinlerde Kutsal Zamanlar, IQ Kültür Sanat Yayıncılık, İstanbul 2008, ss. 18-19.

13 Dölek, agm, s. 376.

14 Gündüz, agm, s. 10. 


\section{1. İslam Dışı Dinlerde Kutsal Zaman Anlayışı}

Tarih boyunca farklı bölgelerde ve farklı kültürlerde kutsalın tezahür ettiği anlar kutsal sayılmış, yaşanan bu anın kutsallığının devam ettirilmek istenmesi ise kutsal zaman kavramını ortaya çıkarmıştır. Bunun bir sonucu olarak da, kutsalın tezahür anları her yıl tekrarlanmış ve söz konusu zaman diğerlerinden ayrılmıştır. Bütün inanışlarda kutsal zaman kavramı mevcuttur. Ancak her toplumun kutsal olarak kabul ettiği zamanlar sahip olunan inanışa, bölgeye, kültüre göre birbirinden farklılık gösterir.

Yahudilikte Tanrı ile olan ilişkiler, Yahudi yaşam tarzı ve Yahudi tarihinin önemli dönüm noktalarına dayalı pek çok kutsal zaman dilimi vardır. Yahudiler tarafından kutsal zamanların belirlenmesine yönelik mevcut tarihlendirme sistemi Eski Ahit temel alınarak oluşturulmuştur. Buna göre düzenlenen Yahudi çağlarının tarihi, yaratılıştan itibaren başlayarak devam etmiş ve sürgün öncesi düzensiz olan Yahudi takvimi, Babil sürgününden sonra yapılan düzenlemelerle şimdiki son şeklini almıştır. Günümüzde kullanılan Yahudi takvimi hem ay hem de güneşin hareketlerine göre hazırlanmış karma bir takvimdir. ${ }^{15}$ Söz konusu takvimde yer alan kutsal zamanların Yahudiler açısından anlam ve önemi birbirinden farklılık gösterir. Bu bağlamda yılbaşı olarak kutlanan Roş Haşana, kefâret günü olarak kabul edilen Yom Kippur, Mısır'dan çıkışın ardından kırk yıl çölde dolaşmaları anısına kutlanan Sukkot, kandil bayramı olarak anılan Hanuka, hatim bayramı olan Simha Tora, Misır esaretinden kurtuluşun anısına kutlanan Fısılh ve Tevrat'ın verilişi anısına kutlanan Şavuot Yahudi takviminde yer alan kutsal gün ve bayramlar içerisinde en öne çıkanlarıdır.

Tarihsel öneme sahip bu bayramların yanı sıra Yahudilerin geçmişte yaşadıkları üzücü ve önemli olaylara ilişkin modern dönemde kutlanan çeşitli anma günleri de vardır. İlk defa modern İsrail Devleti tarafından resmî bayram olarak kutlanmaya başlanan bu günlerden ilki "Matem Günü"dür. Bir diğeri ise, Nazilerin İkinci Dünya Savaşı sırasındaki Yahudi katliamı anısına takvime eklenen "Soykırım ve Direniş Günü"dür. Soykırım ve Direniş Günü' nü ise bundan bir hafta sonra kutlanan ve modern İsrail devletinin kuruluş günü olan "Bağımsızlık Günü" takip etmektedir. ${ }^{16}$

Hıristiyanların dini bayramlarının neredeyse tamamı İsa'nın yaşamıyla doğrudan ilişkilidir. Bunun yanı sıra Kutsal Ruh'la, Meryem'le ve aziz ka-

15 Ünal, age, ss. 117-120.

16 Mahmut Aydın, Anahatlarıyla Dinler Tarihi, Ensar Neşriyat, İstanbul 2010, s. 309.; Ünal, age, ss.158-159. 
bul edilen din adamlarıyla alakalı kutlanan bayramlar da vardır. Yılın çeşitli zamanlarına dağılmış bu kutsal günler çoğunlukla farklı mezheplere göre değişen bir niteliğe sahiptir. Genel uygulamaya bakıldığında, Hıristiyan dünyasının kutlama anlamında Noel, Paskalya ve Pentakost olmak üzere üç evrensel bayramı olduğu görülür. Hıristiyan litürjik takviminin en önemli kutsal zamanları arasında yer alan Noel, İsa'nın doğumu anısına kutlanan bir bayramdır. ${ }^{17}$ İbranice "geçiş" anlamındaki "pesah"tan gelen Paskalya ise, Yahudi geleneğinin Fısıh bayramına denk düşer ve İsa'nın dirilişi anısına kutlanır. Paskalya içerisinde yer alan kutsal hafta boyunca yapılan ayinler vasıtasıyla, İsa Mesih'in hayatının son günleri ve çarmıha gerildiği son anında çektiği çilelerin hatırlanması amaçlanır. ${ }^{18}$ Hıristiyan geleneğin evrensel bayramları içerisinde yer alan Pentakost ise Kutsal Ruh'un havariler üzerine inişinin hatırasına, Paskalya'dan elli gün sonra yedinci Pazar günü kutlanan bir bayramdır. Söz konusu inanışa göre Tanrı, İsa Mesih'in göğe çıkışından sonraki Pentakost Günü, Kutsal Ruh'unu mesihe inananların (havariler) içinde yaşamak üzere göndermiştir. ${ }^{19} \mathrm{Bu}$ nedenle Pentakost günü kiliselerde ayinler düzenlenir. Ayinlerden sonra inanırlar sokaklarda ilahiler söyleyerek yürüyüş yapar, neşeli ve eğlenceli bir şekilde kutlamaları tamamlarlar. ${ }^{20}$ Bunların dışında Hıristiyan dünyası tarafından kutlanan pek çok anma ve kutlama günleri vardır. En yaygın olanlarının bölgeye ve ülkeye göre farklılık gösteren ve daha çok azizlere yönelik düzenlenen kutlama günleri olduğu söylenebilir.

Hindu dini takvimi günlük, haftalık, aylık, yıllık veya daha uzun süren zaman dilimlerinde yapılan pek çok dinsel töreni kapsayan bir içeriğe sahiptir. Takvime bağlı olarak kutlanan ritüellerde ay ve güneş takvimi izlenir. Hindu dinsel geleneğinde yer alan tanrı ve tanrıçalara ait çeşitliliğin kutsal kabul edilen zamanlara da yansıdığı görülür. Nitekim söz konusu inanç sisteminde Krişna, Vişnu, Şiva, Ganeşa gibi tanrılarla; yılanlar, inekler gibi hayvanlarla; 1rmaklar, dağlar, tepeler, bitkiler gibi doğaya ait varlıklarla; Hindu mitolojisinde geçen meşhur olaylarla; ayın evreleri, güneş ve ay tutulmaları, gün dönümleri ve yıldızlarla ilgili kutlamaların yapıldığı sayısız kutsal gün vardır. ${ }^{21}$

17 Noel bayramının tarihlendirmesine ilişkin doğu ve batı kiliseleri arasında farklılık söz konusudur. Batı kiliselerinde Aralık ayının 24'ünü 25'ine bağlayan gece, doğu kiliselerinde ise Ocak ayının 5'ini 6'sına bağlayan gece İsa'nın doğum günü olarak kabul edilir ve kutlamalar buna göre yapilır.

18 Ünal, age, s. 188.

19 Erbaş, age, s. 73.

20 Ünal, age, s. 191.

21 Aydin, age, ss. 88-89. 
Söz konusu günlerin bir kısmı dinsel kaynaklı olmasa da, zaman içerisinde bir takım dinî motiflerle süslenerek dinîleştirilmiştir. ${ }^{22}$

Hinduizm içerisinde yer alan dinî gün ve bayramlar tarih içerisinde bir takım değişikliklere uğrayarak günümüze ulaşmıştır. Değişiklikler dikkate alınarak eski ve yeni dönem olarak ikiye ayrılan kutsal gün ve bayramların, eski döneme ait olanları daha çok doğa olaylarıyla ilgilidir. Ayın evrelerine göre kutlanan "ay ziyafeti" günleri, mevsimlerin geçiş dönemlerinde kutlanan "dört ay" törenleri, sonbahar ve ilkbaharda kutlanan "adak-kutsama" günleri eski dönem Hindu bayramlarına örnek verilebilir. ${ }^{23}$ Yeni dönem içerisinde yer alan dinî bayramlar ise günümüze kadar ulaşan ve Hindu kutsal metinlerinde zikredilen kutsal zamanlardır. Bunlardan en yaygın olarak kutlananları Ram Ravami, Krishna Janamashtami, Holi, Diwali ve Ganesh Chaturthi isimli bayramlardır. ${ }^{24}$

Budist gelenekte ise inancın ortaya çıtığı ilk dönemlerde kabul edilmiş belirli bir dinî takvim yoktur. Sonraki dönemlerde Budizm' in yayılmasıyla birlikte, içinde doğup geliştiği Hinduizm'in de etkisiyle kutsal günler ortaya çımiş ve zamanla dinî bir takvim oluşturulmuştur. Zaman içerisinde meydana gelen Budist takvim Hindu gelenekte olduğu gibi ay takvimine göre belirlenir. Buna göre her ayın birinci (hilal) ve on beşinci (dolunay) günleri uposatha günü olarak kabul edilir. "Ziyaret etmek" anlamına gelen uposatha günlerinin belirlenmesinde her mezhep kendi inanışına göre hareket eder. Budist gelenekte çok önemli bir değere sahip olan bu günler, tarihteki olaylarla ilişkilendirilip kutsallık kazanırlar. ${ }^{25}$ Budist inanırlar Uposatha günlerinde oruç tutan, dua eden ve meditasyon yapan keşişlere katılırlar. Din adamları ise meditasyon yapmak isteyen inanırlara yardımcı olurlar. Bunların yanı sıra hilal ve dolunayı takip eden sekizinci günler de kutsal günler arasında sayılır ve özellikle ruhbanların bu günlerde diğer iki gün gibi oruç tutmaları tavsiye edilir. ${ }^{26}$

Budizm'de yer alan pek çok festival ve tören Buda' nın ve çeşitli grupların kurucularının hayatlarındaki tarihsel ve dinsel olaylar anısına kutlanmaktadır. Ancak dinî bayramlara ait kutlamalar ve bu günlere atfedilen önem değişik ekollere mensup Budist ülkelerde faklılıklar gösterir. Aydın, mezheplere

22 Ünal, age, ss.40.

23 Ünal, age, ss. 40-41.

24 Ayrıntılı bilgi için bkn. Sri Swami Sivananda, Hindu Fasts E Festivals, The Divine Life Society Publication, Uttar Pradesh, Himalayas, India 1997.

25 Ünal, age, s. 86.

26 Ali İhsan Yitik, "Budizm”, Yaşayan Dünya Dinleri, Ed. Şinasi Gündüz, Diyanet İşleri Başkanlı̆̆1 Yayınları, Ankara 2010, ss. 332-333. 
göre farklılık gösteren bu kutlamaları iki gruba ayırarak sınıflandırma yoluna gitmiştir: i. Her bir geleneğe göre tarihleri farklılık arz etmesine rağmen Mahayana ve Mahayana mezhebi dışındaki tüm Budistler tarafından kutlanan dinî bayramlar. ii. Ya sadece Japon Budistler ya da sadece Çin Budistleri tarafından kutlanan dinî bayramlar. ${ }^{27}$ Buna göre farklı mezheplerce kutlanan dinî bayramlar içerisinden en öne çıkanları Vesak, Buda, Mă̆a Puja, Asalha Puja günleri ve Ohigan Festivali' dir. Adı geçen bayramlar haricinde Budist geleneğe ait farklı mezheplerce kutlanan daha pek çok dinî bayram vardır. Budizm'de yer alan bu dinî bayramlar, din adamları ile sıradan halkın bir araya geldiği özel günlerdir. Halk, bayram vesilesiyle tapınaklara gider ve ruhbanlarla birlikte ibadet eder; tapınaklara giderken yanlarında hediye olarak çeşitli yiyecekler ve eşyalar götürürler. Tapınaklarda görevli ruhban sınıfının maddi ihtiyaçlarının önemli bir kısmı bu şekilde karşılanır. ${ }^{28}$

\section{2. İslam'da Kutsal Zaman Anlayışı}

Diğer dinî geleneklerde olduğu gibi İslamiyet'te de birtakım kutsal zaman dilimleri vardır ve genel olarak bakıldığında yıl içerisinde yer alan günlerin dinî açıdan birbiriyle aynı değere sahip olmadıkları görülür. İslamî literatürde "mukaddes" ya da "mübarek" kavramlarıyla ifade edilen söz konusu zaman dilimlerine atfedilen kutsiyet durumu, Kuran'a ve hadislere dayandırılarak ortaya konmuştur. Bu bağlamda İslam dünyası tarafından kullanılan hicrî takvim, Kuran'da yer alan ayetler ve Hz. Peygamber'in hadisleri doğrultusunda oluşturulmuştur. Zira Kuran'da Allah katında ayların sayısının on iki olduğu ifade edilmekte, ${ }^{29}$ hadislerde ise her bir ayın yirmi dokuz günden oluştuğu belirtilmektedir. ${ }^{30}$

Ay'ın Dünya çevresinde dolanımını esas alan hicrî takvimin başlangıcı Hz. Muhammed'in Mekke'den Medine'ye hicret ettiği 622 yılı olarak kabul edilir. Adı geçen tarihlendirme sistemi, toplum içerisinde var olan karışıklıklara bir son vermek amacıyla Hz. Muhammed'in vefatından altı yıl sonra, $\mathrm{Hz}$. Ömer tarafından, hicretin on yedinci yılında oluşturulmuştur. ${ }^{31}$ İslam dünyası tarafından kabul gören hicrî takvim içerisinde Müslümanlarca kutsal sayılan pek çok ay, gün ve gece vardır. Söz konusu kutsal zamanlara ilişkin temel bilgiler sınıflandırılarak aşağıda verilmiştir:

27 Aydin, age, s. 133.

28 Yitik, agm, s. 333.

29 Tevbe $9 / 36$.

30 Buharî, Oruç/ 11.

31 Neşet Çağatay, "Eski Çağlardan Bu Yana Zaman Ölçümü ve Takvim”, Ankara Üniversitesi Ilahiyat Fakültesi, 1978, c. 22, s. 1, ss. 132-133. 
Kutsal Aylar: İslam' da kutsal olarak kabul edilen aylar "haram aylar" ve "üç aylar" olmak üzere iki grup içerisinde ele alınır. Haram aylar, savaşmanın yasaklandığı barış ayları olup Zilkâde, Zilhicce, Muharrem ve Recep aylarından oluşan bir sıralamaya sahiptir. Bunlardan Zilkâde on birinci, Zilhicce on ikinci, Muharrem birinci ve Recep yedinci aya tekâbül eder. Kuran'da "eşhurul hurûm" olarak ifade edilen haram aylarla ilgili hükümler, Hz. İbrahim'e kadar uzanan uzun bir geçmişe sahiptir. İnsanların güven ortamı içerisinde hac ibadetlerini gerçekleştirmelerine hizmet eden bu uygulamayı Hz. İbrahim ve İsmail şeriatından alan cahiliye dönemi Arapları, haram aylar girdiği zaman savaştan ve her türlü şiddet içerikli olaydan uzak durmuşlar, zamanlarını ya ticaretle uğraşarak ya da dinlenerek geçirmeyi tercih etmişlerdir. ${ }^{32}$ Söz konusu uygulama İslamî gelenekte de devam etmiştir. Nitekim Kuran'da haram aylardan şöyle bahsedilir:

"Şüphesiz, Allah'ın gökleri ve yeri yarattığı günkü yazısında, Allah katında ayların sayısı on ikidir. Bunlardan dördü haram aylardır. İşte bu Allah'ın dosdoğru kanunudur. Öyleyse o aylarda kendinize zulmetmeyin." 33

Hz. Muhammed ise Veda Hutbesi'nde haram aylarla ilgili şu sözleri söylemiştir:

“... Hiç şüphe yok ki zaman, Allahu Teâlâ'nın yarattığı gündeki şekil ve nizamına dönmüştür. Sene on iki aydır; onlardan dördü haram aylardır; üçü peş peşe gelir: Zilkâde, Zilhicce, Muharrem ve Şaban'la Cemâzilevvel arasındaki Mudar kabilesinin Receb'i." 34

İslamî gelenekte kutsal kabul edilen aylara ait diğer grubu, hicrî takvime göre Recep, Şaban ve Ramazan aylarından oluşan “üç aylar” oluşturur. Üç aylar, Müslümanların diğer aylara oranla daha fazla ibadet, dua, zikir ve hayır işleriyle meşgul oldukları bir zaman dilimidir. Dinî duyarlılığın söz konusu aylarda daha yoğun bir şekilde yaşanması, bu ayların faziletine ilişkin Hz. Muhammed'den nakledilen rivayetlerle ilişkilidir. Zira nakledilen bu rivayetler, inanırların ibadet yoğunluğunu etkileyen önemli birer faktör olarak kabul edilir. Ayrıca Müslümanlar tarafından kutsal kabul edilen Regaib, Miraç, Berat ve Kadir gecelerinin üç aylar içerisinde yer alması da, bu aylara verilen önemin bir başka nedenidir. Tüm bunların etkisiyle söz konusu aylar, birer arınma ayı olarak, ferdî ve cemaatle icra edilen çeşitli ibadetlerle geçirilir.

32 Sabri Erturhan, "Haram Ayların Fıkhî Okunuşu”, İslam Hukuku Araştırmaları Dergisi, 2009, s.13, ss. $197-198$.

33 Tevbe $9 / 36$.

34 Buhari, Hac/132. 
Kutsal Günler: Yahudilikte cumartesi ve Hıristiyanlıkta pazar olarak kabul edilen haftalık ibadet günü, İslamiyet'te cuma günü olarak belirlenmiştir. Müslüman yaşamında oldukça önemli bir yer teşkil eden cuma günlerinin mübarek olduğunu bildiren pek çok ayet ve hadis vardır. Zira Hz. Muhammed Cuma gününün diğer günlerden farklı ve kutsal olduğunu "Âdem o gün yaratılmış, o gün cennete girmiş ve o gün cennetten çıkarılmıştır; kıyamet de o gün kopacaktır." 35 sözleriyle dile getirmiştir. Cuma gününün en önemli özelliği Cuma namazıdır. İslam inancına göre Cuma günü, Müslümanların işlerini bırakıp camide topluca namaz kılmaları farz kılınmıştır. Müslümanlar Cuma günü ibadet amacıyla bir araya gelir ve birbirleriyle buluşup kaynaşarak aralarındaki toplumsal kaynaşmayı canlı tutarlar. ${ }^{36}$

İslamî gelenek içerisinde yer alan kutsal günlerden bir diğeri, Muharrem Ayı'nın onuncu gününe denk gelen Aşure Günü'dür. Hz. Âdem'in tevbesinin bu günde kabul edildiği, Hz. Nuh'un gemisinin bu günde Cudi Dağı tepesine oturduğu ve Hz. Musa ile İsrailoğulları'nın Firavun'un zulmünden bu günde kurtulduğuna olan inanç nedeniyle Müslümanlar bu güne ayrı bir önem verirler. ${ }^{37}$ Ayrıca bu günde Hz. Muhammed'in torunu Hz. Hüseyin şehit edilmiştir. Birunî’nin el-Âsâr el-Bâkiye isimli eserinde, Kerbelâ olayından sonra iki ayrı aşûre geleneğinin ortaya çıktığına işaret ederek bunları karşılaştırma yoluna gittiği görülmektedir. Buna göre Aşûre Günü, Hz. Hüseyin' in şehit edilmesine kadar olan süreçte, Emevîler tarafından temiz elbiselerin giyildiği, şenlik ve ziyafetlerin düzenlendiği bir bayram günü olarak kutlanırken, Hz. Hüseyin'in şehit edilmesinden sonraki süreçte ise Şiiler tarafından bir yas günü olarak ilan edilmiştir. ${ }^{38}$ Söz konusu ayrılığın günümüzde de devam ettiğini söylemek mümkündür. Nitekim bu günde pişirilip dağıtılan aşure, bir taraftan matemi bir taraftan ise sevinci simgeleyen bir gelenek olarak varlığını sürdürmektedir.

Hicrî takvimin dokuzuncu ayı olan Ramazan ayının son üç gününe denk gelen Ramazan Bayramı, İslam dünyası tarafından kutlanan iki bayramdan ilkidir. Bu bayram, Ramazan ayının başlamasıyla birlikte tutulan orucun tamamlanması sonrasında kutlanır. Ramazan, tüm ay boyunca tutulan oruç nedeniyle bayramdan çok, oruçla özdeşleşen bir kavram olarak

35 Müslim, Cuma/18.

36 Aydin, age, s. 456.

37 Eyüp Baş, "Aşûre Günü, Tarihsel Boyutu ve Osmanlı Dinî Hayatındaki Yeri Üzerine Düşünceler”, Ankara Üniversitesi İlahiyat Fakültesi Dergisi, XLV/2004, say1:1, s. 168. 
karşımıza çıkar. Bu ayda ergenliğe erişmiş tüm erkek ve kadınlar, sabah gün ă̆armadan önce başlayıp akşam gün batana kadar hiçbir şey yiyip içmezler ve cinsî münasebette bulunmazlar. Bu emir kutsal kitap Kuran'da bizzat Allah tarafından belirtilmiştir. ${ }^{39}$ Ayrıca Kuran' 1 n bu ayda indirilmesi nedeniyle Müslümanlar için diğer aylara oranla Ramazan ayının özel bir önemi vardır. Nitekim Kuran'da Ramazan'ın, hakkı batıldan ayırmanın açık delili olduğu ve insanlara doğru yolu gösterdiği bildirilmiştir. ${ }^{40} \mathrm{Bu}$ nedenden dolayı Müslümanlar bu ayı oruç tutarak ve ibadet ederek geçirmeye özen gösterirler. Orucun tamamlanmasıyla birlikte ise üç gün bayram yapılır. Bayramda akrabalar birbirlerini ziyaret eder ve gelenlere şeker ikram edilir. Şeker ikramıyla özdeşleşmesinden dolayı bu bayram halk arasında "Şeker Bayramı" olarak da anılır.

Müslümanlar tarafından kutlanan diğer bayram Kurban Bayramı'dır. $\mathrm{Bu}$ bayram Zilhicce ayının onuncu günü başlar ve dört gün sürer. Maddi durumu yeterli olan her inanır Allah rızası için kurban kesmekle yükümlüdür. Kesilen etlerin bir kısmı fakirlere dağıtılır, bir kısmı ise bayram ziyareti münasebetiyle gelen misafirlere ikram edilir. Müslüman inancına göre Kurban Bayramı toplumsal dayanışma, paylaşma ve yardımlaşma açısından önemli bir işlevselliğe sahiptir.

Kutsal Geceler: İslamî gelenekte Mevlid, Regaib, Miraç, Berat ve Kadir Gecesi olmak üzere beş ayrı gece kutsal kabul edilir ve bu geceler kandil geceleri olarak kutlanır. Söz konusu gecelerin "kandil geceleri" olarak anılması, Osmanlı padişahı II. Selim döneminde (1566-1574) yapılan kutlamalarda, camilerin kandillerle aydınlatılması geleneğine dayanır. ${ }^{41}$ Hicrî takvimde yer alan sıralamaya göre Mevlid, Rebiülevvel ayının on ikinci gününe; Regaib, Recep ayının ilk Cuma gününe; Miraç, Recep ayının yirmi yedinci gecesine; Berat Şaban ayının on beşinci gecesine ve son olarak Kadir Gecesi ise Ramazan ayının yirmi yedinci gecesine denk gelir. Bunlar içerisinden Mevlid Kandili Hz. Peygamber'in doğduğu, Miraç Kandili ise miraca yükseldiği günün anısına kutlanır. Müslümanlar tarafından kutlanan kutsal gecelerden en önemlisi ise Kadir Gecesi' dir. Kadir Gecesi, diğer kutsal gecelerden farklı olarak bizzat Kuran'da işaret edilmiş

39 Bakara 2/183.

40 Bakara 2/185.

41 Nebi Bozkurt, “Kandil” Maddesi, TDV İslam Ansiklopedisi (DİA), İstanbul 2012, c. 24, ss. 300301 . 
ve bin aydan daha hayırlı olduğu vurgulanmıştır. ${ }^{42}$ Müslümanlar kandil gecelerini bireysel ya da toplu bir şekilde ibadet ederek geçirirler ve bu sayede günahlarından arınacaklarına inanırlar.

\section{Kutsal Zamanın İbadet Hayatına Etkisi}

\subsection{Yöntem}

\subsection{Araştırma Grubu}

$\mathrm{Bu}$ araştırma 2015 yılında Çorum ilinde araştırmaya katılmayı kabul eden ve formları eksiksiz bir şekilde dolduran 601 kişi üzerinde yapılmıştır.

\subsection{Veri Toplama Arac1}

$\mathrm{Bu}$ araştırmada, yaş ve cinsiyet sosyodemografik değişkeni ile araştırmacı tarafından hazırlanan ve katılımcıların kutsal zamanla ilgili inanç ve davranışlarını anlamaya yönelik anket formu kullanılmıştır.

\subsection{Uygulama}

Anket formları çalışmaya katılmayı kabul edilen kişilere dağıtılmış ve daha sonra geri toplanmıştır. Yetişkin ve orta yaş grubundaki katılımcılar anket formunu kendileri kullanırken yaşlı örneklem grubundaki kişilerden bazıları soruların okunması noktasında araştırmacıdan destek almıştır.

\section{5. İstati $\underset{Q}{ }$ el Değerlendirme}

İstatistiksel analizler SPSS programında t-testi kullanılarak yapılmıştır. Anlamlılık düzeyi $\mathrm{p}<0,05$ olarak kabul edilmiştir.

\subsection{Bulgular ve Yorum}

\section{Anket Sorularına Verilen Cevapların Frekans Dağılımları:}

Katılımcıların anket sorularına vermiş oldukları cevapların frekans dağılımı Tablo-1'de görülmektedir. Buna göre katılımcıların cinsiyete göre dağılımları, \%49,8'i erkek, \%50,2'si kadın; yaş durumuna göre dağılımı, \%33,3’ü yetişkin, \%33,3'ü orta yaş, \%33,3'ü yaşlı; ramaza durumuna göre dağılımı, \%94,2'si inanıyor, \%5, 2 nanmıyor; ramazan ayının kutsiyetine inananların bu ayda ibadetlerinde bir değişme meydana gelip gelmeme durumuna göre dağılımı, \%100 evet; ramazan ayı dışında günde beş vakit namazlarını düzenli olarak kılma durumuna göre dağılımı, \%51,2'si kılıyor, \%48,8'i kılmıyor; ramazan ayında oruçlarını düzenli olarak tutma durumuna göre dağılımı, \%51,2'si tutuyor, \%48,8'i tutmuyor; diğer zamanlarda düzenli olarak namazlarını kılamasalar da ramazan ayında düzenli olarak

42 Kadir, 97/1-5. 
namazlarını kılma ve oruçlarını tutma durumuna göre dağılımları \%45,2'si evet, \%54,8'i hayır; ramazan ayında zekât verme durumuna göre dağılımı, $\% 62,3$ 'ü evet, \%37,7'si hayır; ramazan ayında diğer zamanlara oranla daha fazla sadaka verme durumuna göre dağılımları, \%94,2'si evet, \%5,8'i hayır; Ramazan ayının kutsiyetine inandığı için bu ayda Kur'an-1 Kerim hatmi yapma durumuna göre dağılımları, \%44,0 evet, \%56,0 hayır; Ramazan ve Kurban Bayramı günlerinin ve arife günlerinin kutsal zaman olduğuna inanma durumuna göre dağılımları, \%94,2 evet, \%5,8 hayır; beş vakit namazını diğer zamanlarda düzenli olarak kılmamakla birlikte Ramazan ve Kurban Bayramı ve arife günlerinin kutsiyetine inandığı için bu günlerde beş vakit namazlarını düzenli kılma durumuna göre dağılımları, \%45,2 evet, \%54,8 hayır; Ramazan ve Kurban Bayramı günleri ve arife günlerinin kutsiyetine inandığı için bu günlerde daha çok sadaka verme durumuna göre dağılım, \%94,2 evet, \%5,8 hayır; Ramazan ve Kurban Bayramı günleri ve arife günlerinin kutsiyetine inandığı için bu günlerde kaza namazı kılma durumuna göre dağılım; $\% 70,5$ evet, \%29,5 hayır; Ramazan ve Kurban Bayramı günleri ve arife günlerinin kutsiyetine inandığı için bu günlerde nafile namaz kılma durumuna göre dağılım; \%51,2 evet, \%48,8 hayır; Recep ve Şaban aylarının kutsal aylar olduğuna inanma durumuna göre dağılım, \%94,2 evet, \%5,8 hayır; Recep ve Şaban aylarında üç aylar orucu tutma durumuna göre dağılım, \%23,0 evet, \%77,0 hayır; Recep ve Şaban aylarının kutsiyetine inandığı için bu aylarda daha çok sadaka verme durumuna göre dağılım, \%94,2 evet, \%5,8 hayır; beş vakit namazını diğer zamanlarda düzenli olarak kılmamakla birlikte Recep ve Şaban aylarının kutsiyetine inandığı için bu günlerde beş vakit namazlarını düzenli kılma durumuna göre dağılımları, \%33,7 evet, \%66,3 hayır; Recep ve Şaban aylarının kutsiyetine inandığı için düzenli üç aylar orucu olmasa da bu aylarda nafile oruç tutmayla ilgili duruma göre dağılımları, \%55,1 evet, $\% 44,9$ hayır; Mevlit, Regaip, Miraç, Berat ve Kadir gecesi gibi kandil gecelerinin kutsiyetine inanma durumuna göre dağılımları, \%94,2 evet, \%5,8 hayır; beş vakit namazını diğer zamanlarda düzenli olarak kılmamakla birlikte kutsiyetine inandığı için bu gecelerde ve gündüzlerinde beş vakit namazlarını düzenli kılma durumuna göre dağılımları, \%45,2 evet, \%54,8 hayır; kandil gecelerinin kutsiyetine inandığı için gündüzleri nafile oruç tutma durumuna göre dağılımları, \%55,1 evet, \%44,9 hayır; kandil gecelerinin kutsiyetine inandığı için bu gecelerde kaza namazı kılma durumuna göre dağılım; \%70,5 evet, \%29,5 hayır; kandil gecelerinin kutsiyetine inandığı için o gece düzenlenen dini sohbet ve programlara gitme durumuna göre dağılım, \%49,3 evet, \%50,7 hayır; kandil gecelerinin kutsiyetine inandığı için bu gecelerde namaz kılma durumuna göre dağılım \%51,2 evet, \%48,8 hayır şeklindedir. 
Tablo-1 Ankete Verilen Cevapların Frekans Dağılımları

\begin{tabular}{|c|c|c|c|}
\hline Sorular & Seçenekler & Sayı & $\%$ \\
\hline Cinsiyet & $\begin{array}{l}\text { Erkek } \\
\text { Kadın }\end{array}$ & $\begin{array}{l}299 \\
301\end{array}$ & $\begin{array}{l}49,8 \\
50,2\end{array}$ \\
\hline Yaş & $\begin{array}{c}21-40 \\
\text { (Yetişkin) } \\
41-60 \\
\text { (Orta Yaş) } \\
60-. . . \\
\text { (Yaşlı) }\end{array}$ & $\begin{array}{l}200 \\
200 \\
200\end{array}$ & $\begin{array}{r}33,3 \\
33,3 \\
33,3\end{array}$ \\
\hline $\begin{array}{l}\text { Ramazan ayının kutsiyetine inanıyor } \\
\text { musunuz? }\end{array}$ & $\begin{array}{l}\text { Evet } \\
\text { Hayır }\end{array}$ & $\begin{array}{c}565 \\
35\end{array}$ & $\begin{array}{c}94,2 \\
5,8\end{array}$ \\
\hline $\begin{array}{l}\text { Bir önceki soruya cevabınız evet ise diğer } \\
\text { zamanlara göre ibadetlerinizde bir değişme } \\
\text { meydana geliyor mu? }\end{array}$ & $\begin{array}{l}\text { Evet } \\
\text { Hayır }\end{array}$ & $\begin{array}{c}565 \\
-\end{array}$ & $\begin{array}{c}100 \\
-\end{array}$ \\
\hline $\begin{array}{l}\text { Ramazan ayı dışında beş vakit namazınızı } \\
\text { düzenli olarak kılıyor musunuz? }\end{array}$ & $\begin{array}{l}\text { Evet } \\
\text { Hayır }\end{array}$ & $\begin{array}{l}307 \\
293\end{array}$ & $\begin{array}{l}51,2 \\
48,8\end{array}$ \\
\hline $\begin{array}{l}\text { Ramazan ayinda orucunuzu düzenli olarak } \\
\text { tutuyor musunuz? }\end{array}$ & $\begin{array}{l}\text { Evet } \\
\text { Hayır }\end{array}$ & $\begin{array}{l}307 \\
293\end{array}$ & $\begin{array}{l}51,2 \\
48,8\end{array}$ \\
\hline $\begin{array}{l}\text { Diğer zamanlarda beş vakit namazınızı } \\
\text { düzenli olarak kılamasanız da ramazan ayında } \\
\text { kılabiliyor ve ramazan orucunuzu da tutuyor } \\
\text { musunuz? }\end{array}$ & $\begin{array}{l}\text { Evet } \\
\text { Hayır }\end{array}$ & $\begin{array}{l}132 \\
160\end{array}$ & $\begin{array}{l}45,2 \\
54,8\end{array}$ \\
\hline $\begin{array}{l}\text { Ramazan ayının kutsiyetine inandığınız için } \\
\text { farz olan zekâtınızı bu ayda veriyor musunuz? }\end{array}$ & $\begin{array}{l}\text { Evet } \\
\text { Hayir }\end{array}$ & $\begin{array}{l}374 \\
226\end{array}$ & $\begin{array}{l}62,3 \\
37,7\end{array}$ \\
\hline $\begin{array}{l}\text { Ramazan ayının kutsiyetine inandı̆̆ınız için bu } \\
\text { ayda diğer zamanlara göre daha fazla sadaka } \\
\text { verir misiniz? }\end{array}$ & $\begin{array}{l}\text { Evet } \\
\text { Hayır }\end{array}$ & $\begin{array}{c}565 \\
35\end{array}$ & $\begin{array}{l}94,2 \\
5,8\end{array}$ \\
\hline $\begin{array}{l}\text { Ramazan ayının kutsiyetine inandığınız için } \\
\text { bu ayda Kur'an-1 Kerim hatmi yapar mısınız? }\end{array}$ & $\begin{array}{l}\text { Evet } \\
\text { Hayır }\end{array}$ & $\begin{array}{l}264 \\
336\end{array}$ & $\begin{array}{l}44,0 \\
56,0\end{array}$ \\
\hline $\begin{array}{l}\text { Ramazan ve Kurban Bayramı günlerinin ve } \\
\text { arife günlerinin kutsal zaman olduğuna inanır } \\
\text { misınız? }\end{array}$ & $\begin{array}{l}\text { Evet } \\
\text { Hayır }\end{array}$ & $\begin{array}{c}565 \\
35\end{array}$ & $\begin{array}{l}94,2 \\
5,8\end{array}$ \\
\hline $\begin{array}{l}\text { Diğer zamanlarda beş vakit namazınızı } \\
\text { düzenli olarak kılamasanız da Ramazan ve } \\
\text { Kurban Bayramı günlerinin ve arife günlerinin } \\
\text { kutsiyetine inandığınız için bu günlerde } 5 \\
\text { vakit namaz kılar mısınız? }\end{array}$ & $\begin{array}{l}\text { Evet } \\
\text { Hayır }\end{array}$ & $\begin{array}{l}132 \\
160\end{array}$ & $\begin{array}{l}45,2 \\
54,8\end{array}$ \\
\hline
\end{tabular}




\begin{tabular}{|c|c|c|c|}
\hline $\begin{array}{l}\text { Ramazan ve Kurban Bayrımı günlerinin ve } \\
\text { arife günlerinin kutsiyetine inandığınız için } \\
\text { bu zaman dilimlerinde daha çok sadaka verir } \\
\text { misiniz? }\end{array}$ & $\begin{array}{l}\text { Evet } \\
\text { Hayır }\end{array}$ & $\begin{array}{c}565 \\
35\end{array}$ & $\begin{array}{c}94,2 \\
5,8\end{array}$ \\
\hline $\begin{array}{l}\text { Ramazan ve Kurban Bayramı günlerinin ve } \\
\text { arife günlerinin kutsiyetine inandığınız için bu } \\
\text { zaman dilimlerinde kaza namazı kılar mısınız? }\end{array}$ & $\begin{array}{l}\text { Evet } \\
\text { Hayır }\end{array}$ & $\begin{array}{l}423 \\
177\end{array}$ & $\begin{array}{l}70,5 \\
29,5\end{array}$ \\
\hline $\begin{array}{l}\text { Ramazan ve Kurban Bayramı günlerinin ve } \\
\text { arife günlerinin kutsiyetine inandığınız için bu } \\
\text { zaman dilimlerinde nafile namaz kılar mısınız? }\end{array}$ & $\begin{array}{l}\text { Evet } \\
\text { Hayır }\end{array}$ & $\begin{array}{l}307 \\
293\end{array}$ & $\begin{array}{l}51,2 \\
48,8\end{array}$ \\
\hline $\begin{array}{l}\text { Recep ve Şaban ayının kutsal zaman dilimi } \\
\text { olduğuna inanıyor musunuz? }\end{array}$ & $\begin{array}{l}\text { Evet } \\
\text { Hayır }\end{array}$ & $\begin{array}{c}565 \\
35\end{array}$ & $\begin{array}{c}94,2 \\
5,8\end{array}$ \\
\hline $\begin{array}{l}\text { Recep ve Şaban ayında üç aylar orucu tutar } \\
\text { mısınız? }\end{array}$ & $\begin{array}{l}\text { Evet } \\
\text { Hayır }\end{array}$ & $\begin{array}{l}138 \\
462\end{array}$ & $\begin{array}{l}23,0 \\
77,0\end{array}$ \\
\hline $\begin{array}{l}\text { Recep ve Şaban ayının kutsal zaman dilimi } \\
\text { olduğuna inandığınızdan dolayı bu zaman } \\
\text { diliminde daha çok sadaka verir misiniz? }\end{array}$ & $\begin{array}{l}\text { Evet } \\
\text { Hayır }\end{array}$ & $\begin{array}{c}565 \\
35\end{array}$ & $\begin{array}{c}94,2 \\
5,8\end{array}$ \\
\hline $\begin{array}{l}\text { Diğer zamanlarda beş vakit namazını düzenli } \\
\text { olarak kılamazsanız Recep ve Şaban aylarında } \\
\text { beş vakit namazınızı kılar mısını? }\end{array}$ & $\begin{array}{l}\text { Evet } \\
\text { Hayır }\end{array}$ & $\begin{array}{c}97 \\
191\end{array}$ & $\begin{array}{l}33,7 \\
66,3\end{array}$ \\
\hline $\begin{array}{l}\text { Recep ve Şaban ayında üç aylar orucumu } \\
\text { düzenli olarak tutmasam da bu aylarda nafile } \\
\text { oruçlar tutmaya çalışır mısınız? }\end{array}$ & $\begin{array}{l}\text { Evet } \\
\text { Hayır }\end{array}$ & $\begin{array}{l}212 \\
173\end{array}$ & $\begin{array}{l}55,1 \\
44,9\end{array}$ \\
\hline $\begin{array}{l}\text { Mevlit, Regaip, Miraç, Berat ve Kadir gecesi } \\
\text { gibi kandil gecelerini kutsal zaman dilimi } \\
\text { kabul ediyor musunuz? }\end{array}$ & $\begin{array}{l}\text { Evet } \\
\text { Hayır }\end{array}$ & $\begin{array}{c}565 \\
35\end{array}$ & $\begin{array}{c}94,2 \\
5,8\end{array}$ \\
\hline $\begin{array}{l}\text { Diğer zamanlarda beş vakit namazınızı } \\
\text { düzenli olarak kılamasanız da Kandil } \\
\text { gecelerinin kutsiyetine inandığınız için bu } \\
\text { gecelerde ve gündüzlerinde } 5 \text { vakit namaz } \\
\text { kılar mısınız? }\end{array}$ & $\begin{array}{c}\text { Evet } \\
\text { Hayır }\end{array}$ & $\begin{array}{l}132 \\
160\end{array}$ & $\begin{array}{l}45,2 \\
54,8\end{array}$ \\
\hline $\begin{array}{l}\text { Kandil gecelerinin kutsiyetine inandığınız } \\
\text { gündüzleri nafile oruç tutar mısınız? }\end{array}$ & $\begin{array}{c}\text { Evet } \\
\text { Hayır }\end{array}$ & $\begin{array}{l}212 \\
173 \\
\end{array}$ & $\begin{array}{l}55,1 \\
44,9 \\
\end{array}$ \\
\hline $\begin{array}{l}\text { Kandil gecelerinin kutsiyetine inandı̆̆ınız için } \\
\text { bu gecelerde kaza namazı kılar mısınız? }\end{array}$ & $\begin{array}{c}\text { Evet } \\
\text { Hayır }\end{array}$ & $\begin{array}{l}423 \\
177 \\
\end{array}$ & $\begin{array}{l}70,5 \\
29,5 \\
\end{array}$ \\
\hline $\begin{array}{l}\text { Kandil gecelerinin kutsiyetine inandığınız için } \\
\text { camiye ya da vakıf, dernek vs. yerlere dini } \\
\text { sohbet ve programlara iştirak eder misiniz? }\end{array}$ & $\begin{array}{c}\text { Evet } \\
\text { Hayır }\end{array}$ & $\begin{array}{l}296 \\
304\end{array}$ & $\begin{array}{l}49,3 \\
50,7\end{array}$ \\
\hline $\begin{array}{l}\text { Kandil gecelerinin kutsiyetine inandığınız için } \\
\text { bu gecelerde nafile namaz kılar mısınız? }\end{array}$ & $\begin{array}{c}\text { Evet } \\
\text { Hayır }\end{array}$ & $\begin{array}{l}307 \\
293\end{array}$ & $\begin{array}{l}51,2 \\
48,8\end{array}$ \\
\hline
\end{tabular}




\section{Cinsiyet İle Kutsal Zaman İnanışı ve Buna Uygun Davranışlar Arasın- daki İlişki}

Cinsiyet ile kutsal zaman inanışı ve buna uygun davranışlar arasındaki ilişki üzerine yapmış olduğumuz istatistiksel analizler Tablo-2' de görülmektedir. Cinsiyet ile diğer değişkenler arasında yaptığımız t-testi sonuçlarına göre; cinsiyet ile Ramazan ayının kutsiyetine inandığı için farz olan zekâtını bu ayda verme, Ramazan ayının kutsiyetine inandığı için bu ayda Kur'an-1 Kerim hatmi yapma, Recep ve Şaban ayında üç aylar orucunu düzenli olarak tutamasa da bu aylarda nafile oruç tutma, kandil gecelerinin kutsiyetine inandığı için bu gecelerin gündüzlerinde nafile oruç tutma ve kandil gecelerinin kutsiyetine inandığı için dini sohbet ve programlara katılma arasında anlamlı bir ilişki çıkmış, diğer değişkenler ile anlamlı ilişki çıkmamıştır. Cinsiyet ile arasında anlamlı ilişki çıkan bu bulgularla ilgili yorumlarımız şu şekildedir;

\section{Zekat Verme}

T-testi sonuçlarına göre Ramazan ayının kutsiyetine inandığı için farz olan zekatını bu ayda vermenin erkekler arasında kadınlardan daha fazla olduğu görülmektedir $(\mathrm{P}<0,05)$. Bu durumun ortaya çıkmasında araştırmaya katılanlar arasında zekat verecek düzeyde zengin olan erkeklerin kadınlardan daha fazla olması neden olmuş olabilir.

\section{Kur'an-1 Kerim Hatmi Yapma}

Verilerin analizinden elde ettiğimiz t-testi sonuçlarına göre Ramazan ayının kutsiyetine inandığı için bu ayda Kur'an-1 Kerim hatmi yapan kadınların anlamlı bir şekilde erkeklerden daha fazla olduğu görülmektedir $(\mathrm{P}<0,05)$. Bu sonucun ortaya çıkmasında kadınların daha fazla bu tür dini etkinliklere ayıracak vakte sahip olmaları, ramazan ayında evlerde sadece kadınların katıldığı mukabele olarak adlandırılan etkinliklerin düzenleniyor olması neden olarak gösterilebilir. Nitekim aynı değişkenin yaş ile arasındaki ilişkiye bakıldığında (bk ablo-3) ramazan ayında Kur'an-1 Kerim hatmi yapanların yaş durumu öre dağılımının en fazla yaşlılık döneminde bulunanlardan oluştuğu bunu orta yaş ve yetişkinlik döneminin takip ettiği görülmektedir. Ülkemizde orta yaş sonları ve yaşlılık dönemi özellikle çalışan kadınların emeklilik dönemini yaşadığı ve kadınlar arasında yapılan dini merasimlere çok daha fazla iştirak ettikleri bir dönem olduğu gözlemlenebilen bir vakıadır. 


\section{Recep ve Şaban Ayında ve Kandil Geceleri Öncesi Nafile Oruç Tutma}

Recep ve Şaban aylarında nafile oruç tutma durumu ile kandil gecelerinin öncelerinde nafile oruç tutma durumunu aynı başlık altında değerlendirmeyi uygun gördük. Çünkü bilindiği gibi Regaip Kandili, Miraç Kandili, Berat Kandili ve Kadir Gecesi bilindiği üç aylar olarak ifade edilen Recep, Şaban ve Ramazan ayı içerisinde idrak edilmektedir. Araştırma verilerinin analizinden elde ettiğimiz t-testi sonuçlarına göre Recep ve Şaban aylarında düzenli olarak olmasa da ara sıra nafile oruç tutma ile Kandil geceleri öncesinde nafile oruç tutmada kadınlar erkeklere oranla daha yüksek düzeyde görülmekte$\operatorname{dir}(\mathrm{P}<0,05)$. Ayrıca her iki değişkene verilen cevaplar incelendiğinde bu iki soruya evet ve hayır şeklinde cevap veren örneklem sayısının eşit olduğu görülmektedir. Dolayısıyla üç aylarda nafile oruç tuttuğunu ifade edenler bu nafile oruçlarını kandil gecelerinin öncesinde ve sonrasında tutmaktadır. Bu sonuçlar nafile oruç konusunda kadınların erkeklerden daha duyarlı olduğunu göstermektedir. Erkeklerin iş ve sosyal hayatta aktif olarak yer alması ve çalışmayı yaptığımız dönemde uzun süre Recep, Şaban ve Ramazan aylarının yaz günlerine denk geliyor oluşu erkekler için oruç ibadetini oldukça meşakkatli kılabilmektedir. Çalışmayan kadınların ise evde oluşlarının oruç tutmak için kendilerine bir avantaj sağladığı düşünülebilir.

\section{Kandil Geceleri Dini Programlara İştirak}

Araştırma verilerinin analizinden elde ettiğimiz t-testi sonuçlarına göre kandil gecelerinde cami, dernek veya vakıflar tarafından düzenlenen dini sohbet programlarına erkeklerin kadınlardan daha fazla katıldığı ve bu durumun istatistiksel açıdan anlamlı olduğu görülmektedir $(\mathrm{P}<0,05)$. Bu durum ülkemizde kadınların ramazan ayında teravih namazı için camiye gitmeleri dışında diğer zamanlarda çok fazla camiye gitmemelerinin bir neticesi olarak görülebilir. Kadının fitne olacağı düşüncesiyle camiye gitmek için dahi olsa evden dışarı çıkmaması gerektiği şeklindeki dini yorumların, bu durumun ortaya çıkmasında etkili olduğu söylenebilir.

Cinsiyet ile diğer değişkenlerin arasında ise istatistiksel açıdan anlamlı bir ilişkiye rastlanılmamıştır. Bu sonuç cinsiyet ile dindarlık arasındaki ilişkiyi ortaya koyması açısından anlamlıdır. Yani kadın ya da erkek olmanın kutsal zaman anlayışı ve bu zaman dilimlerinde araştırmamız kapsamında sorulan farz ve nafile ibadetleri yerine getirme üzerinde bir etkisi bulunmamaktadır. Bu sonuçlar kadınların erkeklere oranla daha dindar oldukları şeklindeki genel kanaatin zıddına bir durumdur. Çünkü deneysel araştırmalar 
genellikle kadınların dindarlığının erkeklerden daha yüksek skorlara sahip olduğunu ortaya koymaktadır. ${ }^{43}$ Fakat bununla birlikte bu konuda tam bir uzlaşı olduğu da söylenemez. Örneğin Argyle ve Beit-Hallahmi (1975) yapmış oldukları araştırmalarda alanda en iyi ulaşılmış sonuçlardan birinin kadınların erkeklerden daha dindar olduğuyla ilgili bulgular olduğunu savunurken, Docenchy (1973), Feltey ve Poloma (1991) gibi araştırmacılar ise kadınların erkeklerden daha dindar olduğuyla ilgili görüşlerin bir yanılgı olduğunu iddia etmektedir. ${ }^{44}$ Alanda cinsiyet ile dindarlık arasında yapılan çalışmalara bakıldığında da birbirinden farklı sonuçların ortaya çıktığı görülmektedir.

Bizim çalışmamızda elde ettiğimiz sonuca benzer bir şekilde Kaya ve Uysal'ın çalışmasında da T-test sonuçlarına göre kadınlar ile erkekler arasında anlamlı fark bulunmamıştır. Bu durum en azından bu araştırma örneklemi için geçerli olmak üzere, dini yönelimleri bakımından iki grubun tutumlarında farklılıktan ziyade benzerlik olduğunun bir göstergesi kabul edilmiştir. Aynı zamanda bu veriler, İslam'ın getirdiği dini ve ahlaki değerlerin günümüz toplumumuzda birleştirici ve kaynaştırıcı rol oynadığının bir göstergesi olarak da değerlendirilmiştir. ${ }^{45}$

Konuya dindarlık tipolojileri açısından bakılacak olursa Arslan'ın Popüler Dindarlık ve Normatif Dindarlık çalışmasında G. Mensching, Patai ve E. Gellner'in çalışmasına paralel olarak normatif dindarlıkta cinsiyetler arasında bir farklılığa rastlanılmazken kadınlar arasında popüler dindarlığın daha yüksek düzeyde görüldüğü tespit edilmiştir. ${ }^{46}$ Nitekim bizim çalışmamızda da zekât dışındaki durumların popüler dindarlık kategorisine giren hususlar olduğu görülmektedir.

Koç'un Türkiye'de yaşayan Müslümanlar üzerine yaptığı çalışmasında da iç güdümlü dindarlık ile cinsiyet arasında anlamlı bir farklılık bulunmuş ve erkeklerin iç güdümlük dindarlık puanları kadınlarınkinden yüksek çık-

43 Inger Furseth, Pål Repstad, "Bireysel Dindarlık", çev.; Mustafa Ulu, Bilimname, 2013, c. XXV, say1: 2, s. 211. (ss. 191-214)

44 Leslie J. Francis, “Dinde Cinsiyet Farklılıklarının Psikolojisi”, Hitit Üni. İlahiyat Fak. Dergisi, 2010/2, c. 9, say1: 18, s. 199-200. (ss.199-211)

45 F. Şule Kaya, Veysel Uysal, "Günümüzde Dindarlık ve Toplumsal Cinsiyet Rolü Algıları Üstüne Bir Araştırma", Uluslararası Sosyal Araştırmalar Dergisi, 2015, c. 8, sayı: 36, s. 654. (ss. 646-662)

46 Mustafa Arslan, "Dinsel Boyutluluğun Sosyolojik Bağlamı: Faktör Analitik Bir Çalışma", Din Bilimleri Akademik Araştırma Dergisi, 2002, c. 2, say1:4, s. 175. (ss. 161-186) 
mıştır. ${ }^{47}$ Fransa'da yaşayan Müslüman-Türk azınlık grup üzerinde yaptığ1 çalışmada ise bu bulgunun tersine kadın örneklem grubunda iç güdümlü dindarlık puanı erkeklerinkinden anlamlı düzeyde yüksek tespit edilmiştir. ${ }^{48}$

Öz'ün çalışmasında ise Namaz, Ramazan Orucu ve dua etme ile cinsiyet arasında pozitif yönde bir korelasyon olduğu tespit edilmiştir. ${ }^{49}$

Karaca tarafından İçsel Dini Motivasyon Ölçeği'nin Türk toplumuna standardizasyonu çalışmasında ölçekten elde edilen puanlar ile cinsiyet değişkeni arasında anlamlı korelasyon tespit edilmiştir. ${ }^{50}$

Ayten' in çalışmasında da Ayten ${ }^{51}$, Yapıc1 ${ }^{52}$, Saroglu' ${ }^{53}$, Hintikka, Koskela, Kontula, Koskela, Koivumaa-Honkanen ve Viinamaki'nin ${ }^{54}$ çalışmalarına paralel olarak kadınların erkeklere oranla daha dindar olduğu tespit edilmiştir. ${ }^{55}$

1980-2000 yılları arasında Batı Avrupa ve Amerika'da yapılan çalışmalar kadınların erkeklerden daha dindar olduğu sonucunu ortaya koyarken, 1990’lı yıllarda ülkemizde yapılan çalışmalarda bu durumun aksine erkeklerin kadınlardan daha dindar olduğu sonucuna ulaşılmıştır. ${ }^{56}$

47 Mustafa Koç, “Demografik Özellikler İle Dindarlık Arasındaki İlişki: Yetişkinler Üzerine Ampirik Bir Araştırma", Uludağ Üniversitesi Illahiyat Fakültesi Dergisi, 2010, c. 19, say1: 2, s. 226. (ss.217-248)

48 Mustafa Koç, “Diasporada Dindarlık ve Umutsuzluk: Fransalı Müslüman-Türk Azınlık Grup Üzerine Ampirik Bir Araştırma", Atatürk Üniversitesi İlahiyat Fakültesi Dergisi, 2013, sayı: 39, s. 429. (ss. 415-444)

49 Satılmış Öz, “Din, Dindarlık İlişkisi Çerçevesinde Öğretmenlerin Dini Anlayış ve Yaşayışlar1", Bozok Üniversitesi İlahiyat Fakültesi Dergisi, 2013, c. 3, sayı: 3, s. 73. (ss. 61-77)

50 Faruk Karaca, "Din Psikolojisinde Metod Sorunu Ve Bir Dindarlık Ölçeğinin Türk Toplumuna Standardizasyonu”, EKEV Akademik Dergisi, 2001, c. 3, sayı: 1, s. 201. (ss.187-201).

51 Ali Ayten, Empati ve Din, İz Yayıncılık, İstanbul 2010, s. 137.

52 Asım Yapıcı, Ruh Sağlı̆̆ı ve Din: Psiko-sosyal Uyum ve Dindarlık, Karahan Kitabevi, Adana 2007, s. 60-61.

53 Vassilis Saroglou, "Gençlerin Dinleri ve Kişilikleri: Belçika'da Yapılan Yeni Araştırmalar", Marmara Üni. İlahiyat Fak. Dergisi, çev.; Veysel Uysal, 2000, say1: 19, ss. 123-144.

54 Hintikka, J., Koskela, T., Kontula, O., Koskela, K., Koivumaa-Honkanen, H., Viinamaki, H., "Religious Attendance and Life Satisfaction in the Finnish General Population", Journal of Psychology and Theology, 2001, say1:29(2), ss. 158-164

55 Ali Ayten, "Din ve Sağlık: Bireysel Dindarlık, Sağlık Davranışları ve Hayat Memnuniyeti İlişkisi Üzerine Bir Araştırma", Din Bilimleri Akademik Araştırma Dergisi, 2013, c. 13. sayı: 3, s. 25-26. (ss. 7-31)

56 Nevzat Tartı, "Dindarlık ve Ahlâk İlişkisi”, IV. Din Şûrası Bildiri ve Müzakereleri, Ankara 2009, s. 355. (ss, 349-361) 
Ayten ve Sağır'ın çalışmasında da kadınların öznel dindarlık ölçeğinden aldıkları ortalama puan $(\mathrm{M}=5,9 ; \mathrm{SD}=1,3)$ her ne kadar erkeklere göre $(\mathrm{M}=$ $5,7 ; \mathrm{SD}=1,4)$ daha yüksekse de aradaki bu fark istatistiksel bakımdan anlamlı değildir. ${ }^{57}$

Yapılan bazı çalışmalarda ise kadınların dinin duygu boyutunda erkeklerin ise bilgi boyutunda daha dindar oldukları ortaya konmaktadır. ${ }^{58}$

2001 yılında yapılan Dünya Değerler Araştırması'na göre erkeklerin \% 76'sı, kadınların ise \% 85'i kendini dindar olarak görmektedir. ${ }^{59}$

Şentepe ve Güven'in çalışmasında da yukarıdaki sonuçlara paralel olarak toplam dindarlıkta kadınların dindarlık düzeyleri erkeklere göre daha yüksek çıkmıştır. ${ }^{60}$

Yakut tarafından lise öğrencileri üzerine yapılan çalışmada da cinsiyet değişkeni ile dindarlık ölçeği puan ortalaması arasında istatistiksel olarak anlamlı birilişkiolmadığı görülmüştür. ${ }^{61}$

Çapçıŏ̆lu'nun İlahiyat Fakültesi öğrencileri üzerinde yaptığ1 araştırmasında ise erkeklere göre kızların muhafazakâr dini tutum düzeyleri daha yüksek, demokratik dini tutum düzeyleri ise daha düşüktür. ${ }^{62}$

Kıraç’ın üniversite öğrencileri üzerinde yaptığı çalışmasında da cinsiyete göre dindarlık eğilimi puanlarında anlamlı bir fark gözlenmemiştir. ${ }^{63}$

Uysal'ın çalışmasında kadınlarla erkekler arasında sadece dindarlığın ibadet boyutunda erkekler lehine anlamlı bir farklılığın olduğunu görülmüştür. ${ }^{64}$

57 Ali Ayten, Zeynep Sağır, “Dindarlık, Dini Başa Çıkma ve Depresyon İlişkisi: Suriyeli Sığınmacılar Üzerine Bir Araştırma", Marmara Üniversitesi Illahiyat Fak. Dergisi, Aralık 2014, c. 47, sayı: 47 , s. 12. (ss. 5-18)

58 Asım Yapıcı, “Dini Yaşayışın Farklı Görüntüleri ve Dogmatik Dindarlık”, Ç.Ü. İlahiyat Fak. Dergisi, 2002/2, c. 2, say1: 2, s. 99. (ss.75-117)

59 Kadir Canatan, Eskiyeni, Ankara 2008, sayı: 10, s. 56. (ss 55-61)

60 Ayşe Şentepe, Metin Güven, "Kişilik Özellikleri ve Dindarlık İlişkisi", Sakarya Üni. İlahiyat Fak. Dergisi, Haziran 2015, c. XVII, sayı: 31, s. 35. (ss. 27-44)

61 Selahattin Yakut, "Lise Öğrencilerinde Dindarlık Düzeyinin Çeşitli Değişkenler Açısından İncelenmesi", İ.Ü. İlahiyat Fakültesi Dergisi, Güz 2012, c. 3, sayı: 2, s. 234. (ss. 223-255).

62 İhsan Çapçığlu, "Sosyo-Politik Tutumlar ve Dindarlık: İlahiyat Fakülteleri Örneğinde Bir Alan Araştırması", F.Üniversitesi İlahiyat Fakültesi Dergisi, 2009, c.1, sayı: 14, s. 171. (143-180).

63 Ferdi Kıraç, “Üniversite Öğrencilerinde Dindarlık Eğilimi ve Anlam Duygusu”, Mukaddime, 2013, sayı: 7, s. 173. (ss. 165- 177).

64 Veysel Uysal, “İslam Dindarlık Ölçeği Üzerine Bir Pilot Çalışma”, İslami Araştırmalar, 1995, c. 8 , say1:3-4, s. 268. (ss., 263-271) 
Tablo-2 Cinsiyet İle Kutsal Zaman İnanışı ve Buna Uygun Davranışlar Arasındaki İlişkinin Karşılaştırılması

\begin{tabular}{|c|c|c|c|}
\hline Kutsal Zaman İnanışı ve Buna Uygun & \multicolumn{3}{|c|}{ Cinsiyet } \\
\hline Seçenekler & $X^{2}$ & $\mathrm{D}$ & $\mathrm{P}$ \\
\hline Yaş & ,013 & 2 & ,993 P >0,05 \\
\hline Ramazan ayının kutsiyetine inanıyor musunuz? & 074 & 1 & $, 373 \mathrm{P}>0,05$ \\
\hline $\begin{array}{l}\text { Ramazan ayı dışında beş vakit namazınızı düzenli } \\
\text { olarak kılıyor musunuz? }\end{array}$ & 2,156 & 1 & ,142 P>0,05 \\
\hline $\begin{array}{l}\text { Ramazan ayında orucunuzu düzenli olarak } \\
\text { tutuyor musunuz? }\end{array}$ & 2,156 & 1 & $, 142 \mathrm{P}>0,05$ \\
\hline $\begin{array}{l}\text { Diğer zamanlarda beş vakit namazınızı düzenli } \\
\text { olarak kılamasanız da ramazan ayında kılabiliyor } \\
\text { ve ramazan orucunuzu da tutuyor musunuz? }\end{array}$ & ,021 & 1 & $, 885 \mathrm{P}>0,05$ \\
\hline $\begin{array}{l}\text { Ramazan ayının kutsiyetine inandığınız için farz } \\
\text { olan zekâtınızı bu ayda veriyor musunuz? }\end{array}$ & 9,848 & 1 & $, 002 \mathrm{P}<0,05$ \\
\hline $\begin{array}{l}\text { Ramazan ayının kutsiyetine inandığınız için bu } \\
\text { ayda diğer zamanlara göre daha fazla sadaka verir } \\
\text { misiniz? }\end{array}$ & ,794 & 1 & ,373 P > 0,05 \\
\hline $\begin{array}{l}\text { Ramazan ayının kutsiyetine inandığınız için bu } \\
\text { ayda Kur'an-ı Kerim hatmi yapar mısınız? }\end{array}$ & 13,771 & 1 & $, 000 \mathrm{P}<0,05$ \\
\hline $\begin{array}{l}\text { Ramazan ve Kurban Bayramı günlerinin ve arife } \\
\text { günlerinin kutsal zaman olduğuna inanır mısınız? }\end{array}$ & ,794 & 1 & ,373 $\mathrm{P}>0,05$ \\
\hline $\begin{array}{l}\text { Diğer zamanlarda beş vakit namazınızı düzenli } \\
\text { olarak kılamasanız da Ramazan ve Kurban } \\
\text { Bayramı günlerinin ve arife günlerinin kutsiyetine } \\
\text { inandığınız için bu günlerde } 5 \text { vakit namaz kılar } \\
\text { mısınız? }\end{array}$ & ,021 & 1 & $, 885 \mathrm{P}>0,05$ \\
\hline $\begin{array}{l}\text { Ramazan ve Kurban Bayramı günlerinin ve arife } \\
\text { günlerinin kutsiyetine inandığınız için bu zaman } \\
\text { dilimlerinde daha çok sadaka verir misiniz? }\end{array}$ & ,794 & 1 & $, 373 \mathrm{P}>0,05$ \\
\hline $\begin{array}{l}\text { Ramazan ve Kurban Bayramı günlerinin ve arife } \\
\text { günlerinin kutsiyetine inandığınız için bu zaman } \\
\text { dilimlerinde kaza namazı kılar mısınız? }\end{array}$ & ,103 & 1 & ,748 $\mathrm{P}>0,05$ \\
\hline
\end{tabular}




\begin{tabular}{|c|c|c|c|}
\hline $\begin{array}{l}\text { Ramazan ve Kurban Bayramı günlerinin ve arife } \\
\text { günlerinin kutsiyetine inandığınız için bu zaman } \\
\text { dilimlerinde nafile namaz kılar mısınız? }\end{array}$ & 2,156 & 1 & $, 142 \quad \mathrm{P}>0,05$ \\
\hline $\begin{array}{l}\text { Recep ve Şaban ayının kutsal zaman dilimi } \\
\text { olduğuna inanıor musunuz? }\end{array}$ & ,794 & 1 & $, 373 \quad P>0,05$ \\
\hline $\begin{array}{l}\text { Recep ve Şaban ayında üç aylar orucu tutar } \\
\text { mısınız? }\end{array}$ & 2,895 & 1 & $, 089 \quad P>0,05$ \\
\hline $\begin{array}{l}\text { Recep ve Şaban ayının kutsal zaman dilimi } \\
\text { olduğuna inandığınızdan dolayı bu zaman } \\
\text { diliminde daha çok sadaka verir misiniz? }\end{array}$ & 794 & 1 & $, 373 \quad \mathrm{P}>0,05$ \\
\hline $\begin{array}{l}\text { Diğer zamanlarda beş vakit namazını düzenli } \\
\text { olarak kılamazsanız Recep ve Şaban aylarında beş } \\
\text { vakit namazınızı kılar mısınız? }\end{array}$ & ,396 & 1 & $, 529 \quad \mathrm{P}>0,05$ \\
\hline $\begin{array}{l}\text { Recep ve Şaban ayında üç aylar orucumu düzenli } \\
\text { olarak tutmasam da bu aylarda nafile oruçlar } \\
\text { tutmaya çalışır mısınız? }\end{array}$ & 20,814 & 1 & $, 000 \quad \mathrm{P}<0,05$ \\
\hline $\begin{array}{l}\text { Mevlit, Regaip, Miraç, Berat ve Kadir gecesi gibi } \\
\text { kandil gecelerini kutsal zaman dilimi kabul ediyor } \\
\text { musunuz? }\end{array}$ & ,794 & 1 & $, 373 \quad P>0,05$ \\
\hline $\begin{array}{l}\text { Diğer zamanlarda beş vakit namazınızı düzenli } \\
\text { olarak kılamasanız da Kandil gecelerinin } \\
\text { kutsiyetine inandığınız için bu gecelerde ve } \\
\text { gündüzlerinde } 5 \text { vakit namaz kılar mısınız? }\end{array}$ & ,021 & 1 & $, 885 \quad P>0,05$ \\
\hline $\begin{array}{l}\text { Kandil gecelerinin kutsiyetine inandığınız için } \\
\text { gündüzleri nafile oruç tutar mısınız? }\end{array}$ & 20,814 & 1 & $, 000 \quad P<0,05$ \\
\hline $\begin{array}{l}\text { Kandil gecelerinin kutsiyetine inandı̆̆ınız için } \\
\text { bu gecelerde kaza namazı kılar mısınız? }\end{array}$ & 103 & 1 & $, 748 \quad P>0,05$ \\
\hline $\begin{array}{l}\text { Kandil gecelerinin kutsiyetine inandığınız için } \\
\text { camiye ya da vakıf, dernek vs. yerlere dini } \\
\text { sohbet ve programlara iştirak eder misiniz? }\end{array}$ & 21,654 & 1 & $, 000 \mathrm{P}<0,05$ \\
\hline $\begin{array}{l}\text { Kandil gecelerinin kutsiyetine inandığınız için } \\
\text { bu gecelerde nafile namaz kılar mısınız? }\end{array}$ & 2,156 & 1 & $, 142 \quad \mathrm{P}>0,05$ \\
\hline
\end{tabular}




\section{Yaş İle Kutsal Zaman İnanışı ve Buna Uygun Davranışlar Arasındaki İlişki}

Biz bu çalışmada ana hatlarıyla yaş ile Ramazan ayının kutsiyetine inanma ve buna uygun olarak Ramazan ayında oruç tutma, zekât-sadaka verme ve Kur'an-1 Kerim okuma gibi bir takım ibadetleri yerine getirme; Ramazan ve Kurban Bayramı günleri ve arife günlerinin kutsiyetine inanma ve bu zaman dilimlerinde farz ve nafile ibadetleri yerine getirme; üç aylar olarak ifade edilen Recep, Şaban ve Ramazan aylarının ve bu aylar içerisinde bulunan Regaip, Miraç, Berat ve Kadir geceleri olarak ifade edilen kandil gecelerinin kutsiyetine inanma ve buna uygun davranışta bulunma arasındaki ilişkiyi inceledik. Ele aldığımız değişkenler İslam ibadet esasları arasında yer alan hususları da ihtiva ettiğinden dolayı konuyu kutsal zaman inancıyla birlikte gelişim dönemleri ve dindarlık açısından değerlendireceğiz.

Yaş ile kutsal zaman inanışı ve buna uygun davranışlar arasındaki ilişkiye ait bulgular Tablo-3'de görülmektedir. T-testi sonuçlarına göre yaş ile kutsal zaman inanışı ve buna uygun davranışların tamamı arasında istatistiksel açıdan anlamlı ilişki görülmektedir $(\mathrm{P}<0,05)$. O yüzden her bir madde için ayrı ayrı değerlendirme yapmak yerine toplu değerlendirme yapılacaktır.

Araştırma sonuçlarına göre kutsal zamana inanma ve buna uygun davranış gösterme durumu tüm davranışlar için en yüksek oranda yaşlılık döneminde görülmektedir. Bu dönemi orta yaş ve yetişkinlik dönemleri izlemektedir. Bu sonuçlar yaş ilerledikçe dindarlaşmada artma olduğuyla ilgili kanaate uygun düşmektedir. Nitekim insanların hayatında dine en az ilgi ve ihtiyaç duyulan dönem genç yetişkinlik olarak adlandırılan 22-30 yaşlarıdır. 30 yaşından sonra ise dine ilginin giderek arttığı kabul edilmektedir. Orta yaş krizinin de yaşandığ1 40'lı yaşlarda geriye kalan hayatı daha anlamlı ve değerli kılmak için manevi yoğunlaşma arzusu uyanır. İbadetler, dini uygulama ve törenler gittikçe önem kazanmaya başlar. Ölüm kaygısının da ciddi bir biçimde yaşandığı yaşlılık döneminde din pek çok yaşlı için yaşamış oldukları sorunlarla başa çımmada önemli bir dayanak teşkil etmektedir. ${ }^{65}$ Nitekim Şentepe'nin çalışmasında da yaşlıların karşılaştıkları bir problem karşısında daha çok olumlu dini başa çıkma tutumunu benimsedikleri görülmektedir. ${ }^{66}$ Ayrıca toplumumuzda yaşlılık dö-

65 Hayati Hökelekli, Din Psikolojisine Giriş, Dem Yay., İstanbul 2010, s. 112; Nevzat Tarhan, "Yaşlılar ve İnanç", Kur'ân Mesajı İlmi Araştırmalar Dergisi, Nisan1998, sayı: 6, s. 46. (43-47)

66 Ayşe Şentepe, "Yaşlılık Döneminde Dini Başa Çıkma”, İnsan ve Toplum Bilimleri Araşstırmaları Dergisi, 2015, c. 4, sayı: 1, s.193. (ss. 186-205). 
nemindeki insanların din dışı çeşitli toplumsal törenlere katılması ve eğlenmesi hoş görülmemesi, yadırganması onları adeta dindarlığa ve ibadetleri yapmaya zorunlu kılmaktadır. ${ }^{67}$ Yaşlılık döneminde dine yönelimde kişinin daha önceki yaşantısının dini boyutunu da göz ardı etmemek gerekir. Çünkü gerek yurt dışı gerekse yurt içinde yapılan bazı çalışmalar yaşlılık döneminde dine yönelimin arttığı yönündeki tezi destekler nitelikte değildir. ${ }^{68}$ Hatta bazı çalışmalarda yaşlılık döneminde dine ilginin zayıfladığı yada tamamen ortadan kaybolduğunu göstermektedir. Dolayısıyla yaşlılık döneminde dini hayat üzerinde belirleyici olan faktörün bu döneme gelinceye kadarki dindarlığın/dini gelişimin izlemiş olduğu seyir olduğu söylenebilir. ${ }^{69}$

Yapılan bazı araştırmalar yaş ilerledikçe dinsel alandaki arayışın gerilerken dini yaşayışın içsel kaynaklarının güçlendiğini göstermektedir. Orta yaş insanının dindarlığın sosyal yönünü ifade eden ve daha çok dışarıda gerçekleştirilen fizik güçle ilgili alanlarda daha sık görüldüğü, ileri yaşlarda ise dua etme, televizyon ve radyodan dini yayınları izleme gibi fiziksel güç gerektirmeyen ilgilerde daha ön plana çıtığı söylenebilir. ${ }^{70}$

Konuyla ilgili olarak literatürde yapılan diğer bazı çalışmaların sonuçları şu şekildedir;

Michael Argyle 30-35 yaşları arasında dini faaliyetlerin tümünde bir düşüş olduğunu 35 yaşından yaşlılığa kadar ise özellikle Tanrı'ya ve ölümden sonrasına inanç konularında gittikçe yükselen bir artış olduğunu ifade etmektedir. Maves'in çalışmasında da ibadet konusunda 30-39 yaşları düşüşün yaşandığı, 40-49 yaşlarında ise bu oranın yükseldiği fakat daha sonra tekrar düştüğü ortaya konmuştur. Birbirinden farklı bu sonuçlar orta yaş döneminde dinin inanç konusunda olmasa bile, dini yaşayış konusunda henüz tam yerleşmiş bir tutumun oluşmadığı şeklinde yorumlanabilir. ${ }^{71}$

Mehmetoğlu'nun yaptığı çalışmada dindar olduğunu belirtenlerin oranı \%74,32 ile en yüksek düzeyde 51-60 yaş grubundadır. ${ }^{72}$ Yaşlılarda dini hayat

67 Hüseyin Peker, Din Psikolojisi, 3. Baskı, Çamlıca Yay., İstanbul 2008, s. 177.

68 Habil Şentürk, Din Psikolojisi, Esra Yayınları, İstanbul 1997, s. 127.

69 Özcan Güngör, "Yaşlılık ve Din”, Din Sosyolojisi El Kitabl, edit.: Niyazi Akyüz, İhsan Çapçığlu, Grafiker Yay., Ankara 2012, s. 258-259.

70 Hasan Kayıklık, Din Psikolojisi, Karahan Kitabevi, Adana 2011, s. 102-103.

71 Mustafa Köylü, Yetişkin Din Eğitiminin Teorik Temelleri, Etüt Yayınları, Samsun 2000, s. 140141.

72 Ali Ulvi Mehmedoğlu, Kişilik ve Din, Dem Yayınları, İstanbul 2004, s. 134-135. 
üzerine yapmış olduğu yüksek lisans tezinde de Buyacı yaşlılık döneminde dine yönelim tespit edilmiştir. ${ }^{73}$

Taplamacıoğlu'nun dönemin şartlarına göre oldukça özverili bir şekilde yaptı̆̆ı ve Türkiye'yi 5 bölgeye ayırarak uyguladığı saha çalışmasında da 50 yaş ve üzeri kişilerin dindarlık düzeylerinin yüksek olduğu tespit edilmiştir. ${ }^{74}$ Ayrıca yaş ilerledikçe ahiret inancında ve dua ibadetinde belirli bir artışın olduğu ve varoluşun anlamının sorgulandığı görülmektedir. ${ }^{75}$

Uysalın çalışmasında elde edilen verilere göre her ne kadar orta yaş dönemindekilerin daha yoğun dini tutum ve davranışlara sahip olma eğiliminde olduğu görülse de t-testi analizi sonuçları ortalamalar arasında istatistiksel bakımdan anlamlı bir fark olmadığını göstermektedir. ${ }^{76}$

Akgül'ün Konya huzurevinde kalan yaşlılar üzerinde yaptığı çalışmada katılımcların inanç (Allah inancl, peygamber inancl, ahret ve yeniden dirilme inancl) ve ibadetlere (farz ve nafile namazı kılma, farz ve nafile orucu tutma, hacca gitme durum ve isteği, Kur'an okuma durumu ve sıklı̆̆l, dua etme sıklı̆̆ı) devam durumları yüksek çıkmıştır. ${ }^{77}$ Hasyılmaz' ${ }^{78}{ }^{78}$ ve Şimşek' in ${ }^{79}$ de huzurevlerinde yaşayan yaşlılar üzerine yaptığı çalışmalarda da bizim çalışmamızın sonuçlarına paralel bir şekilde yaşlılık döneminde dine yönelim olduğu tespit edilmiştir.

Yaşlılık döneminde dini hayatta görülen artışın yaşanılan yer ve ülkede hissedilen siyasi atmosferle de yakından alakalı olduğu düşünülebilir. Nitekim gerek bizim çalışmamızda gerekse Algül'ün, Kayıklık'ın ${ }^{80}$ ve alandaki pek çok çalışmanın aksine Armaner'in Ankara' da yapmış olduğu araştırmada namaz kılan

73 Mehmet Yaşar Buyacı, Yaşlılarda Dini Hayat, Yayınlanmamış Yüksek Lisans Tezi, Atatürk Üniversitesi Sosyal Bilimler Enstitüsü, Erzurum 2002, s. 126.

74 Mehmet Taplamacıŏ̆lu, "Yaşlara Göre Dini Yaşayışın Şiddet ve Kesafeti Üzerine Bir Anket Denemesi", İlahiyat Fakültesi Dergisi, 1962, cilt: X, s. 147. (ss.141-157)

75 Mustafa Koç, "Yaşlılık Döneminde Ölüm Olgusuna Karşı Geliştirilen Tutum ve Davranışlar", EKEV Akademi Dergisi, Bahar 2002, say1: 11, s. 101. (ss. 93-106)

76 Geleneksellik-Çă̆daşlık Bağlamında Türkiye'de Dindarlık ve Kadın, Çamlıca Yayınları, İstanbul 2003, s. 67-72.

77 Mehmet Akgül, "Yaşlılık ve Dindarlık: Dindarlık, Hayattan Zevk Alma ve Mutluluk İlişkisi", Dini Araştırmalar, 2004, c. 7, sayı: 19, s. 26-32. (ss.19-56)

78 Hüseyin Hasyılmaz, Huzurevlerinde Yaşayan Yaşlılarda Dini Hayat (Antalya Örneği), Yayınlanmamış Yüksek Lisans Tezi, Selçuk Üniversitesi Sosyal Bilimler Enstitüsü, Konya 2007, s. 142 .

79 Adeviye Şimşek, Huzurevi Sakinlerinde Dini Yaşayış, Yayınlanmamış Yüksek Lisans Tezi, Çukurova Üniversitesi Sosyal Bilimler Enstitüsü, Adana 2006, s. 87.

80 Hasan Kayıklık, Orta Yaş ve Yaşlılıkta Dinsel Eğilimler, Baki Kitabevi, Adana 2003, s. 149. 
yaşlılık dönemindeki insanların sayısı $\% 20$ olarak tespit edilmiştir. ${ }^{81}$ Seküler bir yaşam tarzının olanca ağırlığıyla hissedildiği, dinden uzaklaşmanın modernleşmenin bir gereği olarak düşünülen dönemlere rastlayan Özbaydar'ın araştırması da sosyo-kültürel seviyesi düşük yaşlı bireylerde Tanrı inancının daha güçlü olduğu tespit edilmiştir. ${ }^{82}$

Batıda yaş ilerledikçe ulaşım meselesi, uygun giyinememe kaygisı ve finansal katkıda bulunamamanın verdiği huzursuzluğun bir sonucu olarak yaşlılık döneminde kiliseye gitme durumunda bir azalma görülürken ${ }^{83}$ bizim toplumumuzda bu tür kaygılar olmadığı için hatta tam tersine yaşlıların camilerde, vakıf, dernek vb. yerlerde düzenlenen etkinliklere katılmaları daha çok teşvik edilmektedir. Tablo-3 incelendiğinde elde ettiğimiz sonuçların da bu görüşü desteklediği görülmektedir. Yaşlıların gerek camide gerekse cami dışı vakıf, dernek vb. organizasyonlar ile bir araya gelişleri özellikle sosyal ilişkileri sınırlı olan yaşlıların sosyal uyumları açısından önem arz etmektedir. ${ }^{84}$

Koç'un yaşlılık döneminde ölüm psikolojisi üzerine yapmış olduğu çalışmada da örneklem grubunu oluşturan deneklerin \%95'i kendilerini kesinlikle dine inanan ve tüm dini görevlerini yerine getirmeye çalışan bireyler olarak tanimlamıştır. ${ }^{85}$

Cimrilik yaşlılık psikolojisinin tipik özelliklerinden biri olarak kabul edilmektedir. ${ }^{86}$ Fakat bizim çalışmamızda yaş ile farz olan zekât ve sadaka verilmesi arasında anlamlı bir ilişki bulunmuştur $(\mathrm{P}<0,05)$. Yani yaş ilerledikçe bu tür davranışlarda artış görülmektedir ve bu durum genel kanaatin aksine bir durumdur. Ya da bu durumu yaşlı insanlar genel anlamda eş, çocuk ve yakınlarına karşı cimri davransa da dini ibadet olarak kabul edilen zekât ve sadaka söz konusu olunca bu cimriliği göstermedikleri şeklinde yorumlayabiliriz.

81 Neda Armaner, Din Psikolojisine Giriş, Ayyıldız Matbaası, Ankara, 1980, c.1, s. 137,

82 Mustafa Koç, “Din Psikolojisi Açısından Yaşlılık Döneminde Dinî Yaşam”, EKEV Akademi Dergisi, May1s 2000, c. 2, say1:2, s. 100. (ss. 97-103)

83 Naci Kula, "Yaşlılık Döneminde Dini İlgi ve Faaliyetler", Uludă̆ Üni. İlahiyat Fak. Dergisi, 1992, c. 4, say1: 4, s. 345. (ss. 343-346)

84 M. Akif Klavuz, "Camilerin Yaşlıların Hayatındaki Yeri”, Yecder III. Ulusal Din Görevlileri Sempozyumu Teliğleri, Yecder Yayınları, İstanbul 2013, s.182-183.

85 Mustafa Koç, "Yaşlılık Döneminde Ölüm Psikolojisi Üzerine Bir Alan Araştırması”, KSÜ İlahiyat Fakültesi Dergisi, 2003, c.1, say1:2, s. 125. (117-143)

86 Mustafa Koç, “Gelişim Psikolojisi Açısından Yaşlılık Döneminde Bireysel ve Ruhsal Gelişim", EKEV Akademi Dergisi, Bahar 2004, say1: 19, s. 87. (ss.77-90) 
Tablo 3 - Yaş İle Kutsal Zaman İnanışı ve Buna Uygun Davranışlar Arasındaki İlişkinin Karşılaştırılması

\begin{tabular}{|c|c|c|c|}
\hline Seçenekler & $X^{2}$ & D & $\mathbf{P}$ \\
\hline $\begin{array}{l}\text { Ramazan ayının kutsiyetine inanıyor } \\
\text { musunuz? }\end{array}$ & 28,824 & 2 & $, 000 \mathrm{P}<0,05$ \\
\hline $\begin{array}{l}\text { Ramazan ayı dışında beş vakit namazınızı } \\
\text { düzenli olarak kılıyor musunuz? }\end{array}$ & 161,741 & 2 & $, 000 \mathrm{P}<0,05$ \\
\hline $\begin{array}{l}\text { Ramazan ayında orucunuzu düzenli olarak } \\
\text { tutuyor musunuz? }\end{array}$ & 161,741 & 2 & $, 000 \mathrm{P}<0,05$ \\
\hline $\begin{array}{l}\text { Diğer zamanlarda beş vakit namazınızı } \\
\text { düzenli olarak kılamasanız da ramazan } \\
\text { ayında kılabiliyor ve ramazan orucunuzu da } \\
\text { tutuyor musunuz? }\end{array}$ & 50,498 & 2 & $, 000 \mathrm{P}<0,05$ \\
\hline $\begin{array}{l}\text { Ramazan ayının kutsiyetine inandığınız } \\
\text { için farz olan zekâtınızı bu ayda veriyor } \\
\text { musunuz? }\end{array}$ & 61,601 & 2 & $, 000 \mathrm{P}<0,05$ \\
\hline $\begin{array}{l}\text { Ramazan ayının kutsiyetine inandığınız için } \\
\text { bu ayda Kur'an-ı Kerim hatmi yapar mısınız? }\end{array}$ & 51,420 & 2 & $, 000 \mathrm{P}<0,05$ \\
\hline $\begin{array}{l}\text { Ramazan ve Kurban bayrımı günlerinin ve } \\
\text { arife günlerinin kutsal zaman olduğuna inanır } \\
\text { mısınız? }\end{array}$ & 28,824 & 2 & $, 000 \quad \mathrm{P}<0,05$ \\
\hline $\begin{array}{l}\text { Diğer zamanlarda beş vakit namazınızı } \\
\text { düzenli olarak kılamasanız da Ramazan } \\
\text { ve Kurban bayramı günlerinin ve arife } \\
\text { günlerinin kutsiyetine inandığınız için bu } \\
\text { günlerde } 5 \text { vakit namaz kılar mısınız? }\end{array}$ & 50,498 & 2 & $, 000 \mathrm{P}<0,05$ \\
\hline $\begin{array}{l}\text { Ramazan ve Kurban bayrımı günlerinin ve } \\
\text { arife günlerinin kutsiyetine inandığınız için } \\
\text { bu zaman dilimlerinde daha çok sadaka verir } \\
\text { misiniz? }\end{array}$ & 28,824 & 2 & $, 000 \mathrm{P}<0,05$ \\
\hline $\begin{array}{l}\text { Ramazan ve Kurban bayrımı günlerinin ve } \\
\text { arife günlerinin kutsiyetine inandığınız için } \\
\text { bu zaman dilimlerinde kaza namazı kılar } \\
\text { mısınız? }\end{array}$ & 170,261 & 2 & $, 000 \mathrm{P}<0,05$ \\
\hline $\begin{array}{l}\text { Ramazan ve Kurban bayrımı günlerinin ve } \\
\text { arife günlerinin kutsiyetine inandığınız için } \\
\text { bu zaman dilimlerinde nafile namaz kılar } \\
\text { mısınız? }\end{array}$ & 161,741 & 2 & $, 000 \quad \mathrm{P}<0,05$ \\
\hline
\end{tabular}




\begin{tabular}{|c|c|c|c|}
\hline $\begin{array}{l}\text { Recep ve Şaban ayının kutsal zaman dilimi } \\
\text { olduğuna inanıyor musunuz? }\end{array}$ & 28,824 & 2 & $, 000 \mathrm{P}<0,05$ \\
\hline $\begin{array}{l}\text { Recep ve Şaban ayında üç aylar orucu tutar } \\
\text { misınız? }\end{array}$ & 32,242 & 2 & $, 000 \quad \mathrm{P}<0,05$ \\
\hline $\begin{array}{l}\text { Recep ve Şaban ayının kutsal zaman dilimi } \\
\text { olduğuna inandığınızdan dolayı bu zaman } \\
\text { diliminde daha çok sadaka verir misiniz? }\end{array}$ & 28,824 & 2 & $, 000 \quad \mathrm{P}<0,05$ \\
\hline $\begin{array}{l}\text { Diğer zamanlarda beş vakit namazını düzenli } \\
\text { olarak kılamazsanız Recep ve Şaban aylarında } \\
\text { beş vakit namazınızı kılar mısınız? }\end{array}$ & 56,730 & 2 & $, 000 \mathrm{P}<0,05$ \\
\hline $\begin{array}{l}\text { Recep ve Şaban ayında üç aylar orucumu } \\
\text { düzenli olarak tutmasam da bu aylarda nafile } \\
\text { oruçlar tutmaya çalışır mısınız? }\end{array}$ & 111,295 & 2 & $, 000 \quad \mathrm{P}<0,05$ \\
\hline $\begin{array}{l}\text { Mevlit, Regaip, Miraç, Berat ve Kadir gecesi } \\
\text { gibi kandil gecelerini kutsal zaman dilimi } \\
\text { kabul ediyor musunuz? }\end{array}$ & 28,824 & 2 & $, 000 \quad \mathrm{P}<0,05$ \\
\hline $\begin{array}{l}\text { Diğer zamanlarda beş vakit namazınızı } \\
\text { düzenli olarak kılamasanız da Kandil } \\
\text { gecelerinin kutsiyetine inandığınız için bu } \\
\text { gecelerde ve gündüzlerinde } 5 \text { vakit namaz } \\
\text { kılar mısınız? }\end{array}$ & 50,498 & 2 & $, 000 \mathrm{P}<0,05$ \\
\hline $\begin{array}{l}\text { Kandil gecelerinin kutsiyetine inandığınız için } \\
\text { gündüzleri nafile oruç tutar mısınız? }\end{array}$ & 111,295 & 2 & $, 000 \mathrm{P}<0,05$ \\
\hline $\begin{array}{l}\text { Kandil gecelerinin kutsiyetine inandığınız için } \\
\text { bu gecelerde kaza namazı kılar mısınız? }\end{array}$ & 170,261 & 2 & $, 000 \mathrm{P}<0,05$ \\
\hline $\begin{array}{l}\text { Kandil gecelerinin kutsiyetine inandığınız için } \\
\text { camiye ya da vakıf, dernek vs. yerlere dini } \\
\text { sohbet ve programlara iştirak eder misiniz? }\end{array}$ & 48,582 & 2 & $, 000 \mathrm{P}<0,05$ \\
\hline $\begin{array}{l}\text { Kandil gecelerinin kutsiyetine inandığınız için } \\
\text { bu gecelerde nafile namaz kılar mısınız? }\end{array}$ & 161,741 & 2 & $, 000 \mathrm{P}<0,05$ \\
\hline
\end{tabular}

\section{Kaynakça}

Adem Özen, Yahudilikte İbadet, Ayışı̆̆ı Kitapları, İstanbul 2001.

Adeviye Şimşek, Huzurevi Sakinlerinde Dini Yaşayış, Yayınlanmamış Yüksek Lisans Tezi, Çukurova Üniversitesi Sosyal Bilimler Enstitüsü, Adana 2006. 
Ali Ayten, “Din ve Sağlık: Bireysel Dindarlık, Sağlık Davranışları ve Hayat Memnuniyeti İlişkisi Üzerine Bir Araştırma", Din Bilimleri Akademik Araştırma Dergisi, 2013, c. 13. sayı: 3, ss. 7-31. -, Empati ve Din, İz Yayıncılık, İstanbul 2010.

--, Zeynep Sağır, “Dindarlık, Dini Başa Çıkma ve Depresyon İlişkisi: Suriyeli Sığınmacılar Üzerine Bir Araştırma", Marmara Üniversitesi İlahiyat Fak. Dergisi, Aralık 2014, c. 47, sayı: 47, ss. 5-18.

Ali Erbaş, Hıristiyanlıkta İbadet, Ayışı̆̆ı Kitapları, İstanbul 2003.

Ali İhsan Yitik, "Budizm”, Yaşayan Dünya Dinleri, edit: Şinasi Gündüz, Diyanet İşleri Başkanlığ1 Yayınları, Ankara 2010, ss. 307-355.

Ali Ulvi Mehmedoğlu, Kişilik ve Din, Dem Yayınları, İstanbul 2004.

Asım Yapıcı, "Dini Yaşayışın Farklı Görüntüleri ve Dogmatik Dindarlık”, Ç.Ü. İlahiyat Fak. Dergisi, 2002/2, c. 2, say1: 2, ss.75-117.

--------, Ruh Sağlığı ve Din: Psiko-sosyal Uyum ve Dindarlık, Karahan Kitabevi, Adana 2007.

Ayşe Şentepe, "Yaşlılık Döneminde Dini Başa Çıkma", İnsan ve Toplum Bilimleri Araştırmaları Dergisi, 2015, c. 4, sayı: 1, ss. 186-205.

-------, Metin Güven, "Kişilik Özellikleri ve Dindarlık İlişkisi”, Sakarya Üni. İlahiyat Fak. Dergisi, Haziran 2015, c. XVII, sayı: 31, ss. 27-44.

Ebû Reyhan El-Birûnî, Maziden Kalanlar (El-Âsâr el-Bâkiye), çev. D. Ahsen Batur, Selenge Yayınları, İstanbul 2011.

Ekrem Sarıkçığlu, Din Fenomenolojisi, Fakülte Kitabevi, Isparta, s. 101.

Emile Durkheim, The Elementery Forms of Religious Life, trans. Karen E. Fields, The Free Press, New York 1995.

Eyüp Baş, "Aşûre Günü, Tarihsel Boyutu ve Osmanlı Dinî Hayatındaki Yeri Üzerine Düşünceler", Ankara Üniversitesi İlahiyat Fakültesi Dergisi, XLV/2004, sayı:1, ss. 167-190..

Faruk Karaca, "Din Psikolojisinde Metod Sorunu Ve Bir Dindarlık Ölçeğinin Türk Toplumuna Standardizasyonu", EKEV Akademik Dergisi, 2001, c. 3, sayı: 1, ss.187-201.

Ferdi Kıraç, “Üniversite Öğrencilerinde Dindarlık Eğilimi ve Anlam Duygusu”, Mukaddime, 2013, say1: 7, ss. 165- 177.

F. Şule Kaya, Veysel Uysal, “Günümüzde Dindarlık ve Toplumsal Cinsiyet Rolü Algıları Üstüne Bir Araştırma", Uluslararası Sosyal Araştırmalar Dergisi, 2015, c. 8, sayı: 36, ss. 646-662.

Habil Şentürk, Din Psikolojisi, Esra Yayınları, İstanbul 1997.

Hasan Kayıklık, Din Psikolojisi, Karahan Kitabevi, Adana 2011.

-------, Orta Yaş ve Yaşlılıkta Dinsel Ĕ̆gilimler, Baki Kitabevi, Adana 2003.

Hayati Hökelekli, Din Psikolojisine Giriş, Dem Yayınları, İstanbul 2010.

Hintikka, J., Koskela ve diğerleri, "Religious Attendance and Life Satisfaction in the Finnish General Population", Journal of Psychology and Theology, 2001, say1:29(2), ss. 158-164.

Hüseyin Hasyılmaz, Huzurevlerinde Yaşayan Yaşlılarda Dini Hayat (Antalya Örneği), Yayınlanmamış Yüksek Lisans Tezi, Selçuk Üniversitesi Sosyal Bilimler Enstitüsü, Konya 2007.

Hüseyin Peker, Din Psikolojisi, 3. Baskı, Çamlıca Yayınları, İstanbul 2008.

Inger Furseth, Pål Repstad, "Bireysel Dindarlık", çev.; Mustafa Ulu, Bilimname, 2013, c. XXV, sayı: 2, ss. 191-214.

İhsan Çapçığlu, "Sosyo-Politik Tutumlar ve Dindarlık: İlahiyat Fakülteleri Örneğinde Bir Alan Araştırması", F. Üniversitesi Illahiyat Fakültesi Dergisi, 2009, c.1, sayı: 14, ss. 143-180.

İlbey Dölek, "Kutsal Bir Zaman Dilimi Olarak Noel Ritüelinin Kutlama Gelenekleri, Alman Luteryanlar Örneği", Turkish Studies, Volume 9/10, Fall 2014, Ankara, ss. 371-390. 
Kadir Canatan, Eskiyeni, Ankara 2008, say1: 10, ss. 55-61.

Leslie J. Francis, “Dinde Cinsiyet Farklılıklarının Psikolojisi”, Hitit Üniversitesi İlahiyat Fak. Dergisi, 2010/2, c. 9, say1: 18, ss. 199-211.

Mahmut Aydın, Anahatlarıyla Dinler Tarihi, Ensar Neşriyat, İstanbul 2010.

M. Akif Klavuz, "Camilerin Yaşlıların Hayatındaki Yeri”, Yecder III. Ulusal Din Görevlileri Sempozyumu Teliğleri, Yecder Yayınları, İstanbul 2013.

Mehmet Akgül, "Yaşlılık ve Dindarlık: Dindarlık, Hayattan Zevk Alma ve Mutluluk İlişkisi", Dini Araştırmalar, 2004, c. 7, say1: 19, ss.19-56.

Mehmet Taplamacıoğlu, "Yaşlara Göre Dini Yaşayışın Şiddet ve Kesafeti Üzerine Bir Anket Denemesi", Ilahiyat Fakültesi Dergisi, 1962, cilt: X, ss.141-157.

Mehmet Yaşar Buyacı, Yaşlılarda Dini Hayat, Yayınlanmamış Yüksek Lisans Tezi, Atatürk Üniversitesi Sosyal Bilimler Enstitüsü, Erzurum 2002.

Mircea Eliade, Dinler Tarihi, İnançlar ve İbadetlerin Morfolojisi, çev. Mustafa Ünal, Serhat Kitabevi, Konya 2005.

--------, The Sacred and The Profane, trans. Willard R. Trask, Harcuort Brace, New York 1959.

Muhammed Hamidullah, "Hicrî Takvim ve Tarihî Arka Planı", Uludağ Üniversitesi İlahiyat Fakültesi Dergisi, çev. Kasım Şulul, s. 9, c. 9, 2000, ss. 671 - 685.

Mustafa Alıcı, Dinler Tarihinin Batılı Öncüleri, İz Yayıncılık, İstanbul 2011.

Mustafa Arslan, "Dinsel Boyutluluğun Sosyolojik Bağlamı: Faktör Analitik Bir Çalışma”, Din Bilimleri Akademik Araştırma Dergisi, 2002, c. 2, sayı:4, ss. 161-186.

Mustafa Karabacak, "Recep Ayının Faziletine Dair Rivayetlerin Değeri”, Selçuk Üniversitesi İlahiyat Fakültesi Dergisi, 2011, ss. 257-276.

Mustafa Koç, “Demografik Özellikler İle Dindarlık Arasındaki İlişki: Yetişkinler Üzerine Ampirik Bir Araştırma", Uludağ Üniversitesi İlahiyat Fakültesi Dergisi, 2010, c. 19, sayı: 2, ss.217-248.

---------, “Diasporada Dindarlık ve Umutsuzluk: Fransalı Müslüman-Türk Azınlık Grup Üzerine Ampirik Bir Araştırma", Atatürk Üniversitesi İlahiyat Fakültesi Dergisi, 2013, sayı: 39, ss. 415444.

---------, “Din Psikolojisi Açısından Yaşlılık Döneminde Dinî Yaşam”, EKEV Akademi Dergisi, May1s 2000, c. 2, say1:2, ss. 97-103.

---------, “Gelişim Psikolojisi Açısından Yaşlılık Döneminde Bireysel ve Ruhsal Gelişim”, EKEV Akademi Dergisi, Bahar 2004, say1: 19, ss. 77-90.

---------, "Yaşlılık Döneminde Ölüm Olgusuna Karşı Geliştirilen Tutum ve Davranışlar", EKEV Akademi Dergisi, Bahar 2002, say1: 11, ss. 93-106.

--------, "Yaşlılık Döneminde Ölüm Psikolojisi Üzerine Bir Alan Araştırması", KSÜ İlahiyat Fakültesi Dergisi, 2003, c.1, say1:2, ss. 117-143.

Mustafa Köylü, Yetişkin Din Eğitiminin Teorik Temelleri, Etüt Yayınları, Samsun 2000.

Mustafa Ünal, Dinlerde Kutsal Zamanlar, IQ Kültür Sanat Yayıncılık, İstanbul 2008.

Münir Yıldırım, "Mircea Eliade'de Kutsal ve Kutsal Zaman Kavramı", Dinî Araştırmalar, c. 10, s. 28, 2007, ss. 59-82.

Naci Kula, "Yaşlılık Döneminde Dini İlgi ve Faaliyetler", Uludağ Üniversitesi İlahiyat Fakültesi Dergisi, 1992, c. 4, say1: 4, ss. 343-346.

Nadir Devlet (Editör), Türk Dünyası'nda Nevruz, Marmara Üniversitesi - Türkiyat Araştırmaları Enstitüsü Yayınları, İstanbul 1999.

Nebi Bozkurt, “Kandil”" Maddesi, TDV İslam Ansiklopedisi (DİA), İstanbul 2012, c. 24, ss. 300-301.

Neda Armaner, Din Psikolojisine Giriş, Ayyıldız Matbaası, Ankara 1980.

Neşet Çağatay, "Eski Çağlardan Bu Yana Zaman Ölçümü ve Takvim”, Ankara Üniversitesi İlahiyat Fakiultesi Dergisi, c. 22, s. 1, 1978, ss. 105-138. 
Nevzat Tarhan, "Yaşlılar ve İnanç", Kur'ân Mesajı İlmi Araştırmalar Dergisi, Nisan 1998, sayı: 6, ss. $43-47$.

Nevzat Tartı, "Dindarlık ve Ahlâk İlişkisi", IV. Din Şûrası Bildiri ve Müzakereleri, Ankara 2009, ss. 349-361.

Ömer Faruk Yavuz, "Kuran'da Kutsal Mekân, Zaman ve Eşya Kavramlarının Sembolik Değeri”, Cumhuriyet Üniversitesi İlahiyat Fakültesi Dergisi, X/2 -2006, ss. 400-401.

Özcan Güngör, "Yaşlılık ve Din", Din Sosyolojisi El Kitabı, edit.: Niyazi Akyüz, İhsan Çapçığlu, Grafiker Yay., Ankara 2012.

Ramazan Adıbelli, Mircea Eliade ve Din, İz Yayıncılık, İstanbul 2011.

Rudolf Otto, The Idea of the Holy, trans. John W. Harvey, Oxford University Press, London 1936.

Sabri Erturhan, "Haram Ayların Fıkhî Okunuşu", İslam Hukuku Araştırmaları Dergisi, s.13, 2009, ss. $195-230$.

Salih Özer, “İslam Düşüncesinde Kutsal (Zaman) Kavramı, Ritüeller/Kutlamalar Örneği”, İslamî Araştırmalar Dergisi, c.18, sayı:13, 2005, ss.305-322.

Salime Leyla Gürkan, Yahudilik, İSAM Yayınları, İstanbul 2008.

Satılmış Öz, "Din, Dindarlık İlişkisi Çerçevesinde Öğretmenlerin Dini Anlayış ve Yaşayışları", Bozok Üniversitesi İlahiyat Fakültesi Dergisi, 2013, c. 3, sayı: 3, ss. 61-77.

Selahattin Yakut, "Lise Öğrencilerinde Dindarlık Düzeyinin Çeşitli Değişkenler Açısından İncelenmesi", İ.Ü. İlahiyat Fakültesi Dergisi, Güz 2012, c. 3, sayı: 2, ss. 223-255.

Sri Swami Sivananda, Hindu Fasts \& Festivals, The Divine Life Society Publication, Uttar Pradesh, Himalayas, India 1997.

Şinasi Gündüz, "Kutsal Hakkında Konuşmak: Dinsel Söylemde Mitos", Milel ve Nihal, cilt 6, say1 1, 2009, ss. 9-26.

Vassilis Saroglou, "Gençlerin Dinleri ve Kişilikleri: Belçika'da Yapılan Yeni Araştırmalar", Marmara Üni. İlahiyat Fak. Dergisi, çev. Veysel Uysal, 2000, sayı: 19, ss. 123-144.

Veysel Uysal, Geleneksellik-Çağdaşlık Bağlamında Türkiye'de Dindarlık ve Kadın, Çamlıca Yayınları, İstanbul 2003.

---------, “İslam Dindarlık Ölçeği Üzerine Bir Pilot Çalışma”, İslami Araştırmalar, 1995, c. 8, sayı:34, ss. 263-271.

Yavuz Unat, “İslam'da ve Türklerde Zaman ve Takvim”, Türk Dünyası Nevruz Ansiklopedisi, edit.: Öcal Oğuz, Atatürk Kültür Merkezi Başkanlığı Yayınları, Ankara 2004. 